\title{
EXECUTOR'S SALE
}

$$
\text { ESTATE }
$$

GEORGE I. SENEY

The American Art Association

$$
\text { Minagers }
$$



1894 


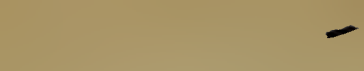




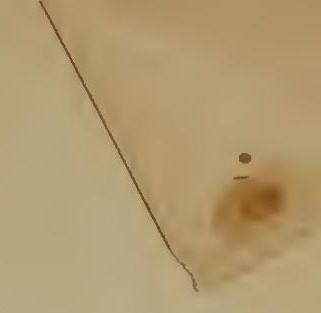





\section{CONDITIONS OF SALE.}

x. The highest Bidder to be the Buyer, and if any dispute arise between two or more Bidders, the Lot so in dispute shall be immediately put up again and re-sold.

2. The Purchasers to give their names and addresses, and to pay down a cash deposit, or the whole of the Purchase-money, if required, in default of which the Lot or Lots so purchased to be immediately put up again and re-sold.

3. The Lots to be taken away at the Buyer's Expense and Risk upon the conclusion of the Sale, and the remainder of the Purchasemoney to be absolutely paid, or otherwise settled for to the satisfaction of the Auctioneer, on or before delivery; in default of which the undersigned will not hold themselves responsible if the Lots be lost, stolen, damaged, or destroyed, but they will be left at the sole risk of the Purchaser.

4. The sale of any $A$ rticle is not to be set aside on account of any error in the description, or imperfection. All articles are exposed for Public Exhibition one or more days, and are sold just as they are, without recourse.

5. To prevent inaccuracy in delivery and inconvenience in the settlement of the Purchases, no Lot can, on any account, be removed during the Sale.

6. Upon failure to comply with the above conditions, the money deposited in part payment shall be forfeited; all Lots uncleared within three days from conclusion of Sale shall be re-sold by public or private Sale, without further notice, and the deficiency (if any) attending such re-sale shall be made good by the defaulter at this Sale, together with all charges attending the same. This Condition is without prejudice to the right of the Auctioneer to enforce the contract made at this Sale, without such re-sale, if he thinks fit.

THOS. E. KIRBY, AUCTIONEER.

AMERICAN ART ASSOCIATION,

Managers. 


\section{ARTISTS REPRESENTED}

\section{Oil Paintings}

Achenback, Andreas, No. I64. Adams, J. Clayton, No. I78.

Artz, Adolphe, Nos. 49, 309.

Baker, W. Bliss, No. 108.

Bedini, P., No. 6.

Billet, Pierre, No. rog.

Bischof, C., No. 308.

Blakelock, Ralph A., Nos. 32, o.

Bochman, G. von, No. I5.

Bok. Theo. de, No. 208 .

Boldini, G., No. 250.

Bonheur, Auguste, No. Iro.

Boughton, Geo. H., Nos. 10I, 291.

Breton, Emile, No. 98 .

Breton, Jules, No. I 36 .

Bristol, John B., No. I37.

Brozic, Vacslav, No. 8.

Bunker, Dennis M., No. 68.

Carlsen, Emile, No. ro3.

Carpentier, E., No. 2 I I

Cazin, Jean-Charles, Nos. II4, 234 .

Chaigneau, F., No. to7.

Chaplin, Charles, No. 158.

Charnay, Armand, Nos. 106, 212.

Chase, Harry, No. ${ }_{3} 8$.

Chase, W. M., Nos. 25I, 292.

Chelminski, Jan von, No. I.

Clausen, George, No. I 7r.

Coast, Oscar R., No. 4.

Corot, J. B. C., Nos. I $8,252$.

Courbet, Gustave, Nos. 209, 297.

Courtois, Gustave, Nos. 36, 67 .

Couture, Thomas, Nos. 50, 206.

Crane, R. Bruce, No. 35.

Daubigny, C. F., Nos. 120, 253, $28 \mathrm{I}$.

Davis, Charles H., Nos. 7,48 , 88, III, I60, 207, 213 .

De Blass, Eugène. No. 105.

Decamps, A. G., No. 257.

De Haas, J. H. L., No. 59.

Delacroix, Eugène, No. 259.

Delphy, C. H., No. 248 .

Demont-Breton, Virginie, No. I67.

De Praters, E., Nos. 64, 92.

De Sauzea, J. D., No. 265.

Deschamps, Louis, Nos. 82, ro4, II $3,159,284$.

Dewey, C. Melville, No. 20.

Diaz, N. V., Nos., I I9, 2 16, 280.

Dielman, Frederick, No. I I.

Dupré, Jules, Nos. II2, I2I, 215 , $254,256,295$.

Eaton, C. Harry, No. Io.

Eckenfelder, T., No. r62.

Edelfeldt, Aibert, Nos. 2I, I02, 203.

Eichelberger, Robert, No. 139 .

Essen, Jan. van, No. 74

Fouace, G., No. 18.

Français, F. L., No. I22.

Fromentin, Eugène, No. 255.

Frost, A. B., No. 326.

Fuller, George, No. Ir5.

Gay, Walter. No. 5 .

Gifford, R. Swain, Nos. 85, 89, II6, 230.
Goubie, Richard, No. I23.

Grolleron, P., No. II7.

Hagborg, A., No. 99.

Hamilton, Hamilton, No. 24.

Harburger, Edmund, Nos. 25, 201 .

Harlamoff, Alexis, Nos. 26,183 , 238.

Harpignies, Henri, No. 269 .

Harrison, Alexander, Nos. I28, I 40, I68, 270, 294.

Harsley, John Calcott, No. 97.

Hart, James M., No. 22.

Hassam, F. Childe, No. 29.

Hawksley, Arthur, No. I84.

Heffner, Carl, Nos. I4, r6r.

Henner, J. J., No. 27.

Henry, E. L., No. 87.

Homer, Winslow, No. I69.

Honrath, T., No. I9.

Inness, George, Nos. 30, 46, 75, I27, 14I, I56, I70, 243, 27I, 273, $277,293,298$.

Isabey, Eugène L. G., No. 290. Israels, Josef, Nos. 83, I57, I99, 272.

Jacque, Chas. E., Nos. I2, I24, 233.

Jacquet, Gustave, No. 200.

Jettel, Eugène, No. 44 .

Jiminez, Luis, No. 204.

Jones, H. Bolton, Nos. 23, 77, I 79 .

Jongkind, J. B., Nos. 197, 263, 283.

Kaemmerer, F. H., No. 34 .

Knaus, Ludwig, Nos. I42, 285.

Knight, D. Ridgway, No. 307

Knip, Henrietta, No. 33.

Koehler, Robert, No. 72 .

Kowalski, A. W., Nos. 37, 2 I4.

Kuehl, G., No. 45.

Lang, Hein rich, No. 3.

Laurens, J. P., No. 244.

Leader, B. W., Nos, 126, 226.

Lefebvre, Jules, Nos. 3r, 163 , 229.

Lerolle, Henri, Nos. 42, 143 , I86, 306.

Leroux, Charles, No. 185 .

Lessi, Tito, No. 125.

Lippincott, W. L., No. I7.

Lohbrichon, T., No. 28.

Madrazo, Raimundo de, No. 274.

Mali, Christian, No. 3 Io.

Maris, Jacques, Nos. 70, 245.

Maris, Willem, No. 60.

Marr, Carl, Nos. 43, roo, 228, 3I $4,320,325$.

Mauve, Anton, Nos. I48, I95: 236 .

Mélin, J., Nos. 22I, 276.

Merk, E., No. 47 .

Mesdag, H. W., Nos. $3^{8}$, 180.

Mettling, Louis, Nos. 145, 149 .

Meyer, Claus, No. 237.

Michel, Georges, Nos. 4I, I47.

Millet, J. F., No. 278.

Millet, F. D., Nos. I 46,267 .

Minor, Robert C., No. 144 .

Molitor, T., No. I73.

Monet, Claude, Nos. I72, 275. 
Moran, Leon, No. Ig6.

Munthe, Ludwig, No. 39 .

Muss-Arnolt, G., No. 2 .

McCord, G. H., Nos. 58, 76, I5०.

McEntee, Jervis, No. 18 r.

Neubert, L., No. 3 II.

Neuhuys, J. A., Nos. 13, 129, 224,315

Nicsy, E., No. 16.

Oelder, G., No. 15x.

Parton, Arthur, Nos. 66, 3 I2.

Pauli, Richard, Nos. 8 r. 300.

Pearce, Charles Sprague, Nos. 242,302 .

Pelouse, L. G., No. I82.

Pettenkoffen, A. von, No. 23 I.

Picknell, W. L., No. 53

Poitevin, Eugene Le, No. 202.

Pokitonow, Ivan, Nos. 217, 218 , $264,266,289$.

Preyer, J. W., No. 69.

Quadrone, G. B., No. 235.

Raffaelli, T. F., No. 249.

Ranger, H. W., Nos. 62, 130, 304 .

Rehn, F. K. M., No. 165 .

Ribera, Roman, No. I53.

Rico, Martin, No. I93.

Robbins, H. W., Nos. 78, r87.

Roelofs, W., Nos. 6I, 188, 24I, 286.

Rousseau, Theodore, No. 258.

Roybet, F., No. 65 .

Ryder, P. P., No. 57 .

Salmon, Th., No. 227.

Salmson, Hugo $\mathbf{F}$., No. 40.

Sanchez-Perrier, E., Nos. I94, 219.

Schleich, R., No. 7 I.

Schreyer, Adolphe, No. 5I.

Smith-Hald, F., No. 80.

Steinheil, Adolphe, No. 52.

Stevens, Alfred, Nos. $55,63,9 x$, I3I, I 52, I66, 240, 287, 299 .

Swoboda, R. L., No. 232.

Tamburini, A., Nos. 54, I92.

Thoren, O. von, Nos. 94, I74, 313.

Thulstrup, Thure de, No. 324 .

Tissot, J., No. 2 Io.

Troyon, Constant, Nos. 132, $^{154}$, $279,296$.

Uhde, F. von, Nos. 79, I33, 246 ,

Van ${ }^{30 x}$ Eiten, H. D. K., No. 9.

Veyrasset, Jules, No. 262.

Vibert, J. G., Nos. 190, 220.

Vollon, A., Nos. 73, 134, 189, 198, $225,247,260,268,288$.

Wahlberg, Alfred, Nos. 86, 93 , $95,176,303$.

Wenglein, Joseph, No. 205.

Weyl, Max, No. 175 .

Wiggins, Carleton, No. 56.

Wood. T. W., No. 305 .

Wyant, A. H., Nos. 84, x35, I55, I9I, 222, 239, 261 .

Ziem, Felix, Nos. 177, 223, 282.

Zügel, H., No. 96 .

\section{Water Colors}

Artz, Adolphe, No. 390.

Caffieri, H., No. 395 .

Chevillard, V., No. $3^{89}$.
Conant, Mrs. C. W., No. 406.

Cuvillon, R. de, No. 386 .

Freer, F. W., No. 4 то

Harpignies, Henri, Nos. 387,408 . $4 \mathrm{II}$.

Heilbuth, Ferdinand, No. 403

Herkomer, Hubert, No. 393 .

Homer, Winslow, Nos. 388,396 , 400.

Israels, Josef, Nos. $384.391,398$.

Knight, D. Ridgway, No. 383 .

Martin, $H$. de, No 4 or.

Moran, Edward, No. $40 \mathrm{~g}$.

Neuhuys, A., No. 385 .

Nicol, Erskine, No. 394.

Richards, W. T., No. 407 .

Rico, Martin, No. 404 .

Roosenboom, Margareta, Nos. $397,399,402$.

Tryon, D. W., No. 405 .

Villegas, José, No. 392.

\section{Drawings}

Brillouin, Georges, No. 321.

L'Hermitte, L. A., No. 322, 323. Etchings

Bracquemond, Felix, Nos. 352, 353.

Brunet-Debaines, A., Nos. 332 , $334,338,342,344,346,349$.

Chauvel, Theophile, Nos. 335 , $337,340,343$.

Dake. C. L., No. 330

Focillon, Victor, No. 329 .

Fox, H. C. No. 33 .

Koepping, Charles, Nos. 347, 348.

Lopisgich, G. A., No. 336 .

Macbeth, R. W., Nos. 327 , 34I.

Rajon, Paul, Nos. 328, 345 .

Walker, Charles A., Nos. 350, 351 .

Waltner, Charles, Nos. 333, 333 “ A," 339.

\section{Engravings}

Atkinson, F., No. 368.

Barnes, G. C., No. $38 \mathrm{r}$.

Bridgewater, H. Scott, No. 370.

Calamatte, Luigi, No. 366 .

Chant, J. J., No. 382 .

Every, G. W. H., No. 367.

François Alphonse, No. 355

Garavaglia, Giovita, No. 356 .

Lefevre, Achille, No. 357 .

Loughi, Giuseppe, No. ${ }_{361 .}$

Mandell, Edward, Nos. 372,373 , 374.

Massard, J. B. R. U., No. 37x.

Mercuri, Paul, No. 379.

Morghen, Raphael, Nos. 358. 359,360 .

Muller, Friederich, Nos. 365 , 378.

Raimond, C., No. 363 .

Simmons, W. H., No. 376 .

Stocks, Lumb, No. 375 .

Tardieu, P. A., No. 362 .

Tompkins, Charles A., No. 377.

Toschi, L., No. 369.

Toschi. Paolo. Nos. 354,363 .

Turrell, Arthur, No. $3^{80}$.

Wille, J. G., No. 364 . 


\section{CATALOGUE}

\section{FIRST NIGHT'S SALE}

Wednesday, February $7_{\text {th }}$

AT CHICKERING HALL

BEGINNING PROMPTLY AT 8 O'CLOCK

No. I

JAN v. CHELMINSKI,

LONDON

A Polish Post-Road

Height, 7 inches ; length, $9 \frac{1}{2}$ inches

Along a Polish post-road jogs a wagon, in which two horse-dealers discuss business, two horses and a colt are tied to the tail of the vehicle, a farmhouse showing in the background. Dated, I885.

No. 2

G. MUSS-ARNOLT,

BAVARIA

\section{Setters}

Heigint, ro inches ; length, I $_{4}$ inches

A pair of setters, in a grassy clearing, have just flushed a woodcock, which flies away into the environing forest. Signed at the left. 
No. 3

HEINRICH LANG,

GERMANY

\section{A Thoroughbred}

Height, $8 \frac{1}{2}$ inches ; width, $7 \frac{1}{4}$ inches

The portrait of a Hungarian thoroughbred, dapple gray. Signed at the right.

No. 4

OSCAR R. COAST.

UNITED STATES

Path in the Adirondacks-Keene Valley

Height, 30 inches; width, 18 inches

An autumnal scene in the North Woods, with the foliage made splendid by the frost. Dated, $\mathbf{I} 886$.

No. 5

WALTER GAY,

FRANCE

\section{Le Decrotteur}

Height, $x_{4}$ inches; width, ro $\frac{1}{2}$ inches

The boots at a French inn, of the period of Louis XV. or XVI., is engaged in purifying and polishing the footgear of the guests. Dated, I886. 
No. 6

\section{P. BEDINI,}

\section{Gallant Impertinences}

Height, $15 \frac{3}{4}$ inches ; length, $20 \frac{1}{4}$ inches

Two young cavaliers have invaded the kitchen of an inn, and are teasing a couple of buxom kitchen maids with mock gallantries, to the terror of the household cat and of an old goose with a progeny of goslings, while a third guest, a wandering soldier, draws a jug of wine from a cask. Signed at the left.

\section{No. 7}

\section{CHARLES H. DAVIS, UNited States}

\section{Autumn Afternoon}

Height, 16 inches; width, ${ }_{3}$ inches

A group of trees on the brink of a pond, under a warm effect of light and color. Signed at the left, r 886 .

\section{No. 8}

VACSLAV BROZIC,

FRANCE

\section{The Messenger}

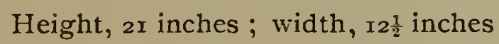

- In the antechamber of a palace a young gentleman page awaits an opportunity to deliver to the master of the house a sealed letter or document, which he holds in his hand. Signed at the right. 
No. 9

H. D. K. VAN ELTEN, United States

\section{The Last Glow}

Height, 18 inches ; length, 30 inches

Across a meadow in the foreground, a farmer's boy, with the aid of his dog, is driving his cows homeward, the landscape being warmed and the distant hills illumined by the fading glow of a placid summer sunset.

No. IO

C. HARRY EATON,

UNITED STATES

\section{Clouds and Sunshine}

Height, 12 inches ; length, 16 inches

A meadow land, drained by a ditch, with a tree in the foreground and a farm in the distance at the left, shadowed by flying autumn clouds and brightened in flashes by the sun. Signed at the right.

No. II

FREDERICK DIELMAN, UNITED STATES My Lady

Height, 9 inches; length, $7 \frac{1}{\frac{1}{6}}$ inches

A bust portrait of a lady in black, wearing a yellow rose at her breast. Signed at the left. 
No. 12

CHARLES ÉMILE JACQUE,

FRANCE

\section{Sheep}

Height, $7 \frac{1}{2}$ inches; length, I2 inches

Two sheep in a stable, one lying down while the other stands watching a couple of hens which are foraging in the feed rack. Signed at the left.

No. 13

J. A. NEUHUYS,

HOLLAND

\section{The Music Lesson}

Height, $25^{\frac{1}{2}}$ inches ; width, 20 inches

In a richly furnished interior of the seventeenth century period an old cavalier is seated, tuning up a mandolin; a young lady, about to be instructed, stands at a table on which are scores.

No. 14

CARL HEFFNER,

Germany

\section{Relics of Old Rome}

Height, I $4^{\frac{3}{1}}$ inches ; length, I8 inches

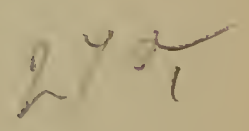

Antique Roman ruins, in the swampy plain of the Campagna, seen by the light of a rising moon. Signed at the left. 
No. 15

GREGOR VON BOCHMANN,

GeRmany

\section{Waiting for the Boats}

Height, II $1 \frac{1}{4}$ inches; length, I8 inches

North Sea fishermen have brought horses to the beach to await the return of the fishing boats, which must be pulled up through the shallow water so as to be safely beached from the breakers. One man indicates to another the approach of a boat, while the patient horses stand with their heads bent to the strong wind. Signed at the right.

No. I6

E. NICSY,

BAVARIA

\section{The Roses}

Height, 24 inches; width, $17 \frac{1}{2}$ inches

On a terrace bench in the garden of a Florentine, villa sits, pensively looking out upon the landscape, a young lady of patrician aspect, in the costume of the fifteenth century; by her side and at her feet are freshly gathered roses.

No. 17

W. H. LIPPINCOTT,

UNITED STATES

\section{Rouge et Noir}

Height, 26 inches ; width, $2 I_{\frac{1}{2}}^{\frac{1}{2}}$ inches

A spirited and vivid portrait of a pretty girl with rich auburn hair, and attired in black, from which contrast the title is derived. Dated, I885. 
No. 18

G. FOUACE,

FRANCE

\section{Still Life}

Height, $18 \frac{1}{4}$ inches ; length, $25 \frac{1}{8}$ inches

A bunch of fresh asparagus, the knife with which it is to be prepared, and the pot in which it is to be boiled. Signed at the right, 1892 .

No. 19

T. HONRATH,

HOLLAND

\section{Breaking Ground}

Height, 18 inches ; width, $12 \frac{1}{2}$ inches

A Dutch ploughman, who has been breaking ground in a fallow field, has halted his horse in order to make repairs to his heavy plough. Signed at the right.

No. 20

\section{CHS. MELVILlE DEWEY, United States}

\section{Sunset}

Height, $\mathrm{I} \mathrm{I}_{\frac{1}{2}}$ inches ; length, $\mathrm{I}_{7}^{\frac{1}{8}}$ inches

A sunset of crimson and gold, upon which the clouds of a stormy night are descending, shows behind a horizon where trees are darkly outlined against it, the foreground being occupied by some trees at the right. 
No. 2 I

ALBERT EDELFELDT,

FRANCE

\section{Autumn Leaves}

Height, 22 inches; width, 18 inches

Walking along a path in a park on the shore of a harbor, in the distance of which may be seen shipping and a city, is a lady who has been gathering autumn leaves, which she carries in a basket on her arm. Dated, I887.

No. 22

JAMES M. HART,

United States

\section{A Summer Pasture}

Height, 30 inches; width, 22 inches

Invested with the rich green livery of midsummer, the pasture lands of Connecticut, with grazing cattle, and ducks paddling in the waters of a meadow ditch, present a picture of perfect peace. Signed at the right, 1882 .

No. 23

H. BOLTON JONES,

United STATES

\section{The Grass Road}

Height, $16 \frac{1}{2}$ inches ; length, 24 inches

A grassy road through fields, with an old stone wall at the left and geese feeding in the road. Signed at the left. 
No. 24

\section{HAMILTON HAMILTON, UNITED STATES}

\section{Veiled Head}

Height, 18 inches ; width, 14 inches

The head of a lady, seen at full front, with her face partially covered by a very delicate veil, against a pale green background, which brings out vividly the vital color of the face. Dated, 1884 .

No. 25

EDMUND HARBURGER, BAVARIA

\section{The Widow}

Height, 16 inches ; length, 24 inches

Alone in her declining age, with only her old cat for a companion, the bereaved and venerable woman mourns in tears the loss which has rendered her humble home so desolate. Dated, 1886.

No. 26

ALEXIS HARLAMOFF,

RUSSIA

Girl's Head

Height, $18 \frac{1}{2}$ inches; width, 14 inches

The head of a little Russian girl, at full front, and wearing a rosary and cross at her neck. Signed at the right. 
No. 27

JEAN JACQUES HENNER,

FRANCE

\section{Ideal Head}

Height, ros inches ; width, $8 \frac{1}{2}$ inches

The head of a young girl, with red hair and a clear, delicate complexion, against a dark background. Signed at the left.

No. 28

TIMOLEON LOHBRICHON,

FRANCE

\section{Cupid's Luncheon}

Height, 23 inches ; width, $16 \frac{1}{2}$ inches

Standing upon a stool, in an artist's studio, his little daughter, who had been regaling herself with her midday bread and soup, is endeavoring with her spoon to feed a plaster bust of Cupid, which is perched on a stand, with the remnant of her repast.

No. 29

F. CHILDE HASSAM,

UNITED STATES

\section{Landscape}

Height, 12 inches; length, 18 inches

The foreground shows a barren hillside, with stony croppings and weedy growths, dark hills making the horizon, while the moon is rising in a sky which reflects the sunset. 
No. 30

\section{GEORGE INNESS,}

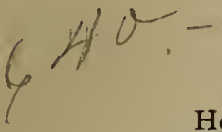

\section{Moonrise}

Height, 20 inches ; length, 30 inches

A clear, bright, moonlight night in Virginia. Some negro cabins are seen in the middle ground, and at a fire in the foreground, at the right, a negro man and woman are preparing to scald a hog which they have killed. Signed at the right.

No. 31

JULES LEFEBVRE,

FRANCE

Diana

Height, $32 \frac{1}{2}$ inches; width, 23 inches

The chaste patron deity of the chase is seen seated on a rock above a pool, with her quiver of arrows beside her, grasping her bow as she turns to look for the origin of some noise which has startled her in her solitude. Signed at the right.

No. 32

\section{RALPH A. BLAKELOCK, UNITED STATES}

\section{Landscape and Indian Fisherman}

Height, $15^{\frac{1}{2}}$ inches ; length, 24 inches

An Indian warrior is fishing at the bank of a forest stream, the landscape being obscured by woodland shade and the gathering gloom of a tempestuous sky. 
No. 33

\section{HENRIETTA KNIP,}

\section{Flowers}

Height, $22 \frac{1}{2}$ inches; width, $16 \frac{8}{4}$ inches

Roses and other flowers grouped in a vase. This ap pears to be an early work of Mme. Henrietta Ronner, now well known as a painter of cats, who was the daughter and pupil of a painter of Amsterdam named Knip. Signed at the right, I850.

No. 34

F. H. KAEMMERER,

FRANCE

\section{The Reader}

Height, 16 inches ; width, $10 \frac{1}{4}$ inches

A lady in a satin toilette of the Directory period, seated in a chair with her feet upon another, is reading a book. Signed at the right.

No. 35

R. BRUCE CRANE,

UNITED STATES

\section{Autumn Woods \\ Height, ro $\frac{1}{4}$ inches; length, $\Upsilon_{4}$ inches}

The forest is invested with a golden glow of color, which is reflected in a brook which traverses it. 
No. 36

GUSTAVE COURTOIS,

FRANCE

\section{A Midday Dreamer}

Height, $17 \frac{1}{2}$ inches ; length, $19 \frac{1}{8}$ inches

Upon a richly cushioned couch a young girl is enjoying her siesta and the pleasant dreams it brings to her. Dated, I $88 \mathrm{r}$.

No. 37

\section{ALFRED WIERNSZ KOWALSKI, POLAND}

\section{$Y_{0}=,-$ Pursued by Wolves}

Height, $14 \frac{\frac{1}{3}}{\frac{1}{3}}$ inches ; length, $19 \frac{\frac{1}{4}}{4}$ inches

A dramatic episode of the Russian winter. A sledge drawn by three horses is pursued at sunset by ravenous wolves, the driver lashing his horses into furious speed over the snow while the passenger empties his revolver at the furious pursuers. Signed at the left.

No. 38

HENDRIK WILLEM MESDAG, HOLLAND

\section{Early Morning}

Height, 20 inches; width, 14 inches

The tide is coming in and has floated a fishing-boat which was beached the night before. A fisherman is wading out to the boat, and the buildings of a town show against the brightening sky in the distance. Signed at the right. 
No. 39

LUDWIG MUNTHE,

\section{Winter Evening}

Height, 2I inches; width, $\mathbf{I} 7 \frac{1}{2}$ inches

The ground is frozen hard and patched with ice and snow. There are houses in the background, and in the snowy road figures of laborers returning from work. A crescent moon rises in the sky. Signed at the left.

No. 40

HUGO F. SALMSON,

FRANCE

\section{The Potato Gatherers}

Height, $x 8$ inches; length, $24 \frac{1}{2}$ inches

In the foreground of an extensive open country, typical of the north of France, male and female field laborers are gathering the tubers from the ground.

No. $4 \mathbf{I}$

GEORGES MICHEL,

FRANCE

\section{River View}

Height, $20_{2}^{\frac{1}{2}}$ inches; length, 28 inches

A broad river flows from left to right. On the left bank are trees, and on the right boats and figures. 
No. 42

\section{HENRI LEROLLE,}

FRANCE

\section{After Work}

Height, 32 inches ; width, $25 \frac{1}{3}$ inches

A haymaker, having completed his day's labor, has halted under a haystack to light his pipe for a smoke on his homeward way. Signed at the right.

No. 43

CARL MARR,

UNITED STATES

\section{Rural Flirtation}

Height, $3^{8 \frac{1}{2}}$ inches ; width, $28 \frac{1}{2}$ inches

A Bavarian peasant girl, tending fowl in the foreground, is saluted by a peasant who has halted his cart in the road crossing the picture, the buildings of a farm showing in the background, bright in the light of a summer morning. Signed at the right, $\mathbf{I} 888$.

No. 44

EUGENE JETTEL,

FRANCE

\section{The Bathing Place}

Height, 26 inches ; length, $40 \frac{1}{2}$ inches

In a stream, dusky with the shadows of the trees upon its bank, some boys are bathing at sunset on a summer day. 
No. 45

G. KUEHL,

BAVARIA

\section{At the Organ}

Height, $37 \frac{1}{4}$ inches; width, $28 \frac{1}{2}$ inches

In the organ loft of a Dutch village church, a girl is practising at a voluntary on the instrument. Signed at the right.

No. 46

GEORGE INNESS,

UNiTED STATES

In Westchester County, N. Y.

Height, $25 \frac{1}{2}$ inches ; length, 35 inches

A pasture traversed by a brook is on the right, and at the left a farm on a hillside. On the rise of ground behind the pasture is a clump of trees. The effect is that of early evening in midsummer. Signed at the left, 1852.

No. 47

E. MERK,

FRANCE

\section{A Court Martial.}

Height, $\mathrm{I}_{4}$ inches ; length, 29 inches

Around a table a number of veteran officers, in the costume of the seventeenth century, are interrogating a cavalier, who stands erect before them, for judgment upon some dereliction of service. 
No. 48

CHARLES H. DAVIS, UNITED STATES

\section{Edge of a Wood in Autumn}

Height, I9 inches; length, 25 inches

The verge of a forest, arrayed in the brilliant vestments of the decaying year, is seen in the tender, hazy atmosphere of Indian summer. Dated, $\mathbf{I} 885$.

No. 49

ADOLPHE ARTZ;

HOLLAND

\section{Humble Industry}

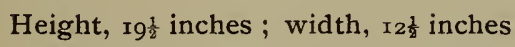

In a Dutch interior of the humbler class an old peasant woman is seated, engaged in sewing. Signed at the right.

No. 50

THOMAS COUTURE,

FRANCE

$2 \% 0, \quad$ Female Head

Height, $2 \mathbf{I}_{\frac{1}{2}}$ inches ; width, 18 inches

A vigorously painted portrait, facing to the right. Signed at the left. 
No. $5 \mathbf{I}$

ADOLPHE SHREYER,

FRANCE

\section{A Standard Bearer}

Height, $32 \frac{1}{2}$ inches ; width, $26 \frac{1}{2}$ inches

An Arab standard bearer, mounted on a spirited barb, reins his steed up, and waving his banner over his head, turns in his saddle to call his comrades on to the combat.

No. 52

ADOLPHE STEINHEIL, FRANCE

\section{The Print Collectors}

Height, 33 inches ; width, $26 \frac{2}{3}$ inches

Three amateurs of engraving are discussing the prints which one of them exhibits to his friends out of his collection. Signed at the right, 1879.

No. 53

WILliam L. PICKNELL, UNited States Silvery Morning

Height, $2 \mathrm{I}_{\frac{1}{2}}^{\frac{1}{2}}$ inches ; length, $35_{\frac{1}{2}}^{\frac{1}{2}}$ inches

A scene upon the New England coast, where the land is intersected by inlets from the sea, the foreground showing a strip of shore, and beyond the water the landscape making a horizon line against the luminous, gray morning sky. 
No. 54

\section{A. TAMBURINI,}

\section{$b 4.4$. "Just Another Drop!"}

Height, 20 inches ; length, 30 inches

Two mendicant friars, in the cellar of an inn, each with a glass in his hands, are begging a buxom girl, who is filling bottles from a barrel of wine, for another libation, which she teasingly refuses, while the landlord looks on from the cellar entrance in amusement. Signed at the right.

No. 55

\section{ALFRED STEVENS, BELGIUM}

\section{On the Balcony}

Height, $x 8$ inches ; width, 15 inches

A lady is seated, at a shaded window which opens on a garden bright with summer. She wears a black demi-toilette, as if expecting to receive a visitor. Signed at the left, 1885 .

No. 56

\section{CARLETON WIGGINS, UNITED STATES}

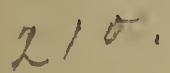

\section{Near the Sea}

Height, $\mathrm{I}_{3}$ inches; length, 20 inches

In one of the salt meadows of Long Island, a sleek brown cow, with white markings, is seen in profile, her head elevated as if at some passing sound. 
No. 57

P. P. RYDER,

United States

\section{Aunt Lottie}

Height, $2 \mathrm{I}$ inches ; width, $\mathbf{I 7}$ inches

An old negress, evidently the ruling power of the kitchen, presides over a pot which she has set to boil upon the stove. Signed at the right.

No. 58

GEORGE H. MCCORD, UNited States

\section{A Somerset Trout Stream}

\section{Height, 18 inches ; length, 30 inches}

Under an afternoon effect, with the stream at the right of the foreground and a road at the left, is seen a typical English landscape, with farms and hills in the distance. Signed at the left.

No. 59

J. H. L. DE HAAS,

BELGIUM

\section{Belgian Cattle}

Height, 18 inches ; width, $12 \frac{1}{2}$ inches

Well-fed cattle passing through a pasture field, the procession led by three sleek cows. Signed at the right. 
No. 60

WILLEM MARIS,

HOILAND

\section{The Duck House}

Height, I $4 \frac{1}{2}$ inches ; width, ro inches

At the right of a small stream willow-trees grow upon the bank, and a duck cage is moored in the water, the denizens of which, startled by some unusual sound, are rising in flight from their foraging in the brook.

No. 6r

\section{WILLIAM ROELOFS,}

HOLLAND

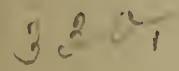

\section{At Pasture}

Height, 9 inches ; length, 16 inches

Cattle are pasturing in richly turfed meadows which are traversed by a small watercourse. Signed at the left.

No. 62

HENRY W. RANGER, UNiTED STATES

Near Laaren, Holland

Height, I2 inches; length, I6 inches

A Dutch pasturage, with cattle, the ground traversed by a drainage ditch. Signed at the right. 
No. 63

ALFRED STEVENS,

FRANCE

\section{In Reverie}

Height, $\mathrm{x} 8$ inches ; width, $13 \frac{1}{2}$ inches

A young lady with pensive expression is seated upon the broad ledge of the window of a French country house, outside of which are seen gardens, villas, and a distant windmill.

No. 64

E. DE PRATERS,

HOLLAND

Landscape and Cattle

Height, 27 inches ; width, $12 \frac{1}{2}$ inches

A study of a dun-and-white bull in a midsummer meadow, with cows at pasture in the background.

No. 65

FERDINAND ROYBET,

FRANCE

\section{Testing the Wine}

Height, $16 \frac{1}{2}$ inches ; width, $x 2 \frac{3}{4}$ inches

A cavalier in rich attire of the seventeenth century stands at a table in a sumptuous apartment, holding up to the light a glass in which he has been testing the wine which is in a flagon before him. Signed at the left. 
No. 66
ARTHUR PARTON,
United States

\section{In the Arkville District}

Height, ${ }_{7} 7$ inches ; length, 24 inches

A midsummer scene in Delaware County, N. Y., with a stream and grazing cattle. Signed at the left, I886.

No. 67

GUSTAVE COURTOIS,

FRANCE

\section{The Plot of the Story}

Height, $25^{\frac{1}{2}}$ inches ; width, 23 inches

A lady reclines against the richly tapestried and decorated wall of a mansion, and, with her open novel in her lap, ponders and speculates upon the possible termination of the plot which interests her. Dated, I884.

No. 68

DENNIS M. BUNKER,

UNITED STATES

\section{A Breton Fishing Town}

Height, $\mathrm{I}_{3}$ inches ; length, 18 inches

The foreground is composed of a stone quay, upon which figures are seen, and beyond which fishing-boats are moored, with sea and sky for background. Dated, I 884 . 
No. 69

JOHANN WILHELM PREYER,

GERMANY

\section{Still Life}

Height, ro inches; length, $x_{3} \frac{1}{2}$ inches

Plums, grapes, peaches, cherries, and other fruit on a marble slab. Signed at the right.

No. 70

JACQUES MARIS,

HOLLAND

\section{The Sand Wagon}

Height, $8 \frac{1}{2}$ inches; length, $x 4 \frac{1}{4}$ inches

A wagon which has been loading sand on the sea beach is returning inland down the slope of the dunes which outline themselves against the sky. Signed at the left.

No. $7 \mathrm{I}$

ROBERT SCHLEICH,

BAVARIA

\section{Wayside Refreshment}

Height, $5^{\frac{3}{4}}$ inches; length, 8 inches

An aristocratic coach of the period of the seventeenth century, which is escorted by two mounted cavaliers, has halted at a humble wayside inn, where the horses are refreshed with water from the well while the gentry invigorate themselves with stronger tipple. Signed at the right. 
No. 72

ROBERT KOEHLER,

BAVARIA

\section{The Socialist}

Height, Ió inches; width, I2 inches

A powerful character study of a radical sociological reformer expounding his views with violent gesticulations and fiery energy to his audience, from a rostrum. The type is German. The picture was painted in Munich, and exhibited at the N. A. D., New York, in 1885.

No. 73

\section{ANTOINE VOLLON, \\ FRANCE}

\section{After the Dessert}

Height, $9 \frac{1}{2}$ inches ; length, ro inches

On a table backed by a red curtain are seen the dishes which have been used to serve the dessert to a dinner, with such remnants of their original contents as the appetites of the feasters have left. Signed at the left.

No. 74

\section{JAN VAN ESSEN,}

HOLLAND

\section{A Dutch Peasant}

Height, $7 \frac{1}{2}$ inches; length, $12 \frac{1}{3}$ inches

A Dutch peasant wheels a barrow loaded with grass from a grassfield which is seen in the middleground. Signed at the right. 
No. 75

GEORGE INNESS,

United States

\title{
Autumn Evening
}

Height, 20 inches; length, 30 inches

Looking out from the edge of a grove, with a group of trees at the right, one sees a meadow intersected by a stream, and shadowed by trees. The ruddy glow of an autumnal sunset enriches the scene. Dated, 1885.

No. 76

GEORGE H. MCCORD, United States

\section{Devonshire Downs, near Ilfracombe}

A landscape, characteristic of the south of England, with sheep grazing and a hint at showers in the sky. Signed at the right.

\section{No. 77}

\section{H. BOLTON JONES,}

United States

\section{Winter Evening}

\author{
Height, $24 \frac{1}{3}$ inches ; length, 40 inches
}

A creek, bordered by thickets and small trees, winds into the foreground through a landscape buried in snow and obscured by the shades of evening, the last color of sunset showing in the sky. Signed at the left. 
No. 78

HORACE W. ROBBINS, UNiTED STATES

\section{2,1, A Summer Afternoon}

Height, 20 inches ; length, 30 inches

A scene in the level region of the Adirondack country, with a stream crossing the foreground, and trees upon its banks, and in the extreme distance the mountains describing a horizon.

No. 79

FRITZ VON UHDE,

BAVARIA

Consolation

Height, $25^{\frac{1}{2}}$ inches ; length, $3 \frac{1}{2}$ inches

Three women are leaving a mournful and lonely cemetery overhanging the sea, one consoling the other, while the third follows behind. A sad, gray sky, in which the clouds are driven by a bleak, chill wind, lowers over the scene. The composition is in itself an episode of modern village life, but it is intended also by the artist, according to his manner, to symbolize the departure of the three Marys from the tomb of our Saviour. Signed at the left.

No. 80

F. SMITH-HALD,

NORWAY

\section{After Vespers}

Height, 24 inches ; length, $39 \frac{1}{2}$ inches

Country-women are returning from service at the village church at evening, along a road extending through widespreading common lands. Signed at the left. 
No. 8I

RICHARD PAULI,

UNITED STATES

\section{Crepuscule}

Height, ${ }_{4}$ irches ; length, 36 inches

Over the landscape, which has sunk into the peace and rest of a midsummer evening, the moon is rising in serene beauty, in a sky warm with the lingering reflection of the sunset; at the right, a farmhouse being dimly revealed under a grove of trees.

No. 82

LOUIS DESCHAMPS,

UNited States

\section{Wild Flowers}

\section{Height, $22 \frac{1}{2}$ inches ; width, 16 inches}

The three-quarter-length figure of a little French peasant girl who has been gathering wild flowers during her work in the fields, and is now forming them into a bouquet.

No. 83

JOSEF ISRAELS,

HOLLAND

\section{The Wood Gatherer}

Height, $1 \mathrm{I}$ inches ; width, 8 inches

A Dutch peasant, gathering fagots at the edge of a grove at evening, is lopping a branch to add to his bundle. Signed at the left. 
No. 84

\section{ALEXANDER H. WYAN'T, UNIted States}

\section{The Edge of the Wood}

Height, ro inches ; length, $\mathrm{I}_{4}$ inches

The view is outward from the forest, with a strong sunset showing among the tree-trunks. Signed at the right.

No. 85

R. SWAIN GIFFORD,

UNITED STATES

\section{A Haystack}

Height, I $5 \frac{1}{2}$ inches; width, I2 inches

At the right, in a stubble field, is a tall haystack, with a ladder leaning against it and a cow reposing at its base, the farm showing behind, and the sky indicating cloudy weather.

No. 86
ALFRED
WAHLBERG,
FRANCE

\section{Evening at Egremont, Sweden}

Height, $17 \frac{1}{2}$ inches ; length, $29 \frac{1}{2}$ inches

The wide expanse of water of a Swedish fiord extends itself placidly under the friendly light of evening, while at the left a portion of the shore is seen. 
No. 87

E. L. HENRY,

UNITED STATES

\section{The Latest Village Scandal}

Height, 17 inches; length, 25 inches

A farmer, driving his wife and baby on a visit, meets on a road which descends a hill a neighbor who is returning from the grist mill. Each pulls up to exchange salutations, and the neighbor relates the latest gossip of the village, which he has acquired upon his visit to the mill. The family man listens with an undisguised grin to the petty scandal, while even the expression of severity which his wife assumes does not conceal the interest she takes in the narration. Signed at the left, 1885 .

No. 88

CHARLES H. DAVIS,

United States

\section{The Three Trees}

Height, $14 \frac{1}{1}$ inches; length, $2 \mathrm{I}$ inches

In the centre of the level land are the three trees which give it its title. A pool of water is in the foreground, and a farm at the left. The scene is illumined by a rising moon. Signed at the left, $188_{5}$.

$$
\text { No. } 89
$$

R. SWAIN GIFFORD, United States

\section{The Harvest Season}

Height, to inches; length, 18 inches

A field with a haystack at the right, and brush behind, crows hovering over the gleanings of the harvest. Dated I88I. 
No. 90

\section{RALPH A. BLAKELOCK, UNITED STATES}

\section{Moonlight}

Height, $x 2$ inches ; width, ro inches

A mellow moonlight dimly reveals the trees upon the banks of a stream in the foreground, and lends mystery to the distant hills which close in the prospect.

No. 91

\section{ALFRED STEVENS, \\ BELGIUM}

\section{Good Fortune}

Height, rof inches ; width, $8 \frac{1}{2}$ inches

A young woman, seated on a couch in her luxuriously appointed apartment, has been playing at fortune with the cards, and wears an expression of pleasure at having dealt herself a lucky omen from the pack. Signed, at the left, on top.

No. 92

E. DE PRATERS,

HOLLAND

\section{Cattle}

Height, 26 inches; width, 21 inches

In the foreground, which is shaded by trees at the left, cattle are in a pool, while in the middle ground others graze in a meadow, brightened by gleams from a sky with high-riding clouds. 
No. 93

ALFRED WAHLBERG,

FRANCE

\section{Moonlight in Norway}

Height, 29 inches; length, $43 \frac{1}{\frac{1}{2}}$ inches

Over the expanse of water which occupies the foreground, and which gains silvery gleams from the moonlight, the shore is seen at the left in the middle distance, with some houses on the bank.

No. 94

OTTO VON THOREN,

FRANCE

\section{Waiting for the Tow}

Height, $3 x_{\frac{1}{2}}^{\frac{1}{2}}$ inches ; length, $39 \frac{1}{2}$ inches

On the bank of a broad stream, a relay of tow horses, supervised by a mounted driver, is patiently awaiting the arrival of the barges which it will be their duty to haul to the next stage of the journey.

No. 95

ALFRED WAHLBERG, FRANCE

\section{A Landscape in Norway}

Height, 29 inches ; length, $43^{\frac{1}{2}}$ inches

The level water, illuminated by the warm reflection of a golden sunset, occupies the left of the picture, with the shore on the right, and trees in full summer foliage shadowing the bank. 
No. 96

\section{HEINRICH ZU̇GEL,}

GERMANY

\section{The Dog's Toilet}

Height, $28 \frac{1}{2}$ inches ; length, $4^{8}$ inches

The shepherd is washing his dog in a little creek in the pasture, while his sheep crop the grass under the willow-trees. A village on a hill shows in the distance. Signed at the right, 1889.

No. 97

JOHN CALCOTT HARSLEY, ENGLAND

\section{Romeo}

Height, $40 \frac{1}{3}$ inches ; width, $32 \frac{1}{\frac{1}{2}}$ inches

At the first break of dawn the young wooer stands, under Juliet's window, from which still depends the rope ladder by which he has descended into the garden, holding his sword ready for prompt use in case of attack from any of the retainers of the house. Dated, 1875 .

No. 98

EMILE BRETON,

FRANCE

\section{Night and Peace}

Height, $43^{\frac{1}{2}}$ inches ; length, 55 inches

The last fading fires of sunset are seen through trees in the background, and the moon is rising in the darkening sky. In the foreground at the left is a church, at whose vestry door a couple of monks are about to enter. Signed at the left. 
No. 99

\section{AUGUST HAGBORG,}

FRANCE

\section{Love and Industry}

Height, 35 inches; length, 52 inches

Seated upon the gunwale of a fishing-boat, which is drawn up on the shore, a young girl industriously mends a broken net, while her sweetheart, a stalwart young fisherman, divides his time between puffing his pipe and entertaining her with his discourse.

No. 100

CARL MARR,

UNited States

\section{Evening and Moonrise}

Height, $4{ }^{1 \frac{1}{2}}$ inches ; length, 66 inches

A shepherd, marshalling his flock homeward at the end of day, has encountered on the way his sweetheart, who is driving her cows back from the grazing ground to the stall, and they have halted to exchange their endearments, while the flocks take care of themselves. Dated, iss6.

No. IOI

GEORGE H. BOUGHTON,

ENGLAND

\section{The Day's Ending}

Height, ${ }_{46}^{\circ}$ inches ; length, $5 \mathrm{r}$ inches

In the long twilight of early harvest time in England, men and women are returning from their employments of the day in the fields. In the foreground a shepherd, driving his flock to the fold, greets his sweetheart, who has been gleaning after the reapers. Cottages show beside a road which crosses the middle ground, and a pale moon rises in the sky. 
No. 102

\section{ALBERT EDELFELDT, $\quad$ FINLAND}

\section{Preparing for the Launching}

Height, $52 \frac{1}{2}$ inches ; width, $36 \frac{1}{2}$ inches

Some boys, seamen and fishermen of the future, who have constructed miniature vessels for themselves, are putting the final touches to them on the shore previous to launching them for a trial trip. Signed at the right, $t 886$.

No. 103

EMILE CARLSEN,

DENMARK

\section{Une Plumeuse}

Height, $69 \frac{1}{3}$ inches ; width, 52 inches

A comely market woman is despoiling a big duck of its feathers, previous to delivering it to the purchaser, while a variety of other fowl await their turn to be plucked. It is the custom among French gourmets to examine certain classes of fine fowl with their feathers on, having them plucked after purchase, and an expert plumeuse or plucker at the markets has a trade to herself. Signed at the right, 1885 . 


\title{
SECOND NIGHT'S SALE
}

\author{
Thursday, February 8th
}

AT CHICKERING HALL

BEGINNING PROMPTLY AT 8 O'CLOCK

No. 104

LOUIS DESCHAMPS,

FRANCE

\section{Magdalen}

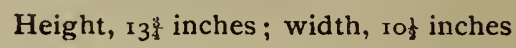

With her elbow resting on a table, and her head supported by her hand, she is absorbed in the perusal of a manuscript which is spread before her. Signed at the left.

No. 105

EUGENE DE BLAAS,

BAVARIA

\section{A Venetian Girl}

Height, I inches ; width, 9늘 inches

The head of a young Venetian girl with the Titian tint of hair, and in characteristic costume. Signed at the right, 1883 . 
No. 106

ARMAND CHARNAY,

FRANCE

\section{Summer Pleasures}

Height, $16 \frac{1}{2}$ inches ; width, $12 \frac{1}{2}$ inches

A lady and a little child are descending the steps of a chateau into the garden to gather flowers, the child carrying a basket. Their little dog prances and gambols at the foot of the steps, and barks at them to hasten and give him his morning run. Signed at the right.

No. 107

F. CHAIGNEAU,

FRANCE

\section{Guardians of the Flock}

Height, 16 inches ; width, $12 \frac{8}{4}$ inches

A shepherd, at the close of day, leads his fleecy flock home to shelter, while his faithful dog acts as rearguard and brings the stragglers into line. Signed at the left.

No. 108

\section{WILLIAM BLISS BAKER, UNited StATES}

\section{Autumn Woods}

Height, 16 inches ; length, 21 inches

A woodland interior, with a stony bedded brook, the foliage of the trees gorgeous in autumnal crimson and gold. Signed at the right. 
No. 109

PIERRE BILLET,

FRANCE

\section{Harvest Time}

Height, 26-1 inches; width, I9 inches

A French peasant woman marches in advance, bearing a sheaf of newly reaped wheat, while two children, similarly burdened, follow her in single file. Signed at the left, I88I.

No. IIO

AUGUSTE BONHEUR, FrANCE

\section{At the Stream}

Height, 20 inches ; length, 28 inches

A group of cattle have halted at a stream in the foreground, with a hilly country showing behind in the light of late afternoon. Signed at the right.

No. I I I

CHARLES

H. DAVIS,

UNITED STA'TES

\section{Autumn Woods}

Height, I9 inches; length, 25 inches

A grove of those spindling trees characteristic of a certain phase of French landscape, denuded by autumn frosts and winds. Signed at the left, 1885 . 
No. II 2

JULES DUPRÉ,

FRANCE

\section{The Farm}

Height, $12 !$ inches ; length, $16 \frac{1}{2}$ inches

The farm is at the right, with some cows, overlooking a road which is shaded by an old oak tree at the left. Signed at the right.

No. II 3

LOUIS DESCHAMPS,

\section{Child Reading}

Height, 16 inches ; width, I2 inches

\section{FRANCE}

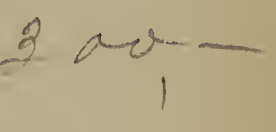

A little girl intently studying her lessons of the day in a school-book which she holds in her hand. Signed at the right.

No. I I4

JEAN-CHARLES CAZIN,

FRANCE

\section{A French Road}

Height, ${ }_{5}$ inches; length, 18 inches

A village road, with houses and trees at the right, under a showery sunset sky. Signed at the left. 
No. I 5

GEORGE FULLER,

UNITED STATES

\section{Shearing the Donkey}

Height $\mathrm{I}_{3}$ inches; length, 18 inches

A farmer is shearing his donkey in the harnyard, fowl pecking around, and a woman passing through the yard. The color is a warm glow of sunset. Signed at the left.

No. II6

R. SIVAIN GIFFORD,

UNITED STATES

\section{A Wood Clearing}

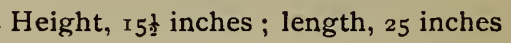

A clearing made by the wood-choppers in one of the scrubby woods characteristic of Long Island, the scene enriched with autumnal tints Signed at the right.

No. I 17

P. GROLLERON,

FRANCE

\section{The Picket}

Height, $9_{\frac{3}{3}}^{3}$ inches ; length, $12 \frac{\pi}{4}$ inches

A French soldier, in fuil field equipment, has been posted on picket duty at a road crossing a hilltop, from which he can observe any movement in the plain below or approaches by the road on either side. Signed at the left. I883. 
No. 1 I 8

J. B. C. COROT,

FRANCE

\section{Landscape}

Height, to inches; length, 14 inches

A farm shows in the middle ground, a woman at the left driving two cows to pasture. The period is summer, and the time morning. Signed at the right.

No. II9

NARCISSE VIRGILE DIAZ, FRANCE

\section{Evening}

Height, $9 \frac{1}{3}$ inches ; length, $17 \frac{1}{2}$ inches

In a plain dotted with trees, cattle and figures are seen in the foreground. The sun is setting, and its last rays harmonize sky and landscape. Signed at the left.

No. 120

\section{CHARLES FRANÇOIS DAUBIGNY, FRANCE}

\section{Low Tide}

Height, to inches; length, ${ }^{7} 7_{\frac{1}{4}}$ inches

A study on the Channel coast. The receding tide has left the rocks of the foreground bare, and a woman searches in them for shellfish and edible seaweed. In the distance the cliffs of the shore jut out into the sea. The time is late afternoon, closely approaching sunset. Signed at the left. 
No. I 2 I

JULES DUPRÉ,

FRANCE

\title{
The Village
}

Height, 6 inches ; length, 8 inches

A humble French village, the houses built on either side of a road, in which a female peasant walks. Signed at the left.

No. 122 .

FRANÇOIS LOUIS FRANÇAIS, FRANCE

\section{At the Lake of St. Cloud}

Height, $\mathrm{Ir}_{\frac{1}{2}}$ inches ; length, $\mathrm{I}_{4}$ inches

A glade in the forest of St. Cloud, with the sunset showing through the trees at the left. Signed at the left.

No. 123

RICHARD GOUBIE,

FRANCE

\section{The Morning of the Hunt}

\author{
Height, $9 \frac{1}{2}$ inches ; length, $12 \frac{1}{2}$ inches
}

A mounted trumpeter in the livery of a French hunt, and a kennelman on foot with his pack of hounds, are awaiting the arrival at the meet of the gentry, who are to engage in the chase for the stag. Signed at the left, I 886. 
No. 124
CHARLES
EMILE JACQUE,
FRANCE

\section{Feeding the Pets}

Height, $7 \frac{1}{2}$ inches ; length, ro inches

At the door of a humble farm-house, two little children are feeding the fowl of the farm, which scramble for the crumbs and morsels thrown to them. Signed at the left.

No. 125

TITO LESSI,

\section{A Puritan Reading}

Height, Ig inches; width, ${ }_{3} \frac{3}{4}$ inches

An old man, in the plain garb of the seventeenth-century nonconformists of the better class, is seated under a window, reading his Scriptures. Signed at the right, 1885 .

No. 126
BENJAMIN W. LEADER,
ENGLAND

\section{A Welsh River}

Height, 16 inches ; length, $25 \frac{8}{9}$ inches

The placid river crosses the foreground, with the verdant bank beyond. Signed at the left, 1885 . 
No. 127

GEORGE INNESS,

UNITED STATES

\section{The Sun's Farewell}

Height, 20 inches; length, 30 inches

Beyond a foreground of grassy meadow, a stream whose banks are lined with willow trees crosses the picture; the scene being warmed by a colorful sunset sky, and softened by the haze of the period we know as Indian summer. Signed at the right, $388_{5}$.

No. 128

ALEXANDER HARRISON, UNITED STATES After the First Frost

Height, 20 inches ; length, 30 inches

The foreground shows a meadow pool, with frost colored foliage in the background, and a flock of crows rising against the sky. Signed at the right.

No. 129

ALBERT NEUHUYS,

HOLLAND

\section{The Morning Greeting}

Height, I $9^{\frac{1}{2}}$ inches ; width, $x_{9}$ inches

A young mother, in the attire of a Dutch peasant wife, has lifted her baby from its wicker cradle and stands holding it up in her hands while they exchange the first kiss of the day. Signed at the left. 
No. I 30

HENRY W. RANGER,

UNited STATES

\section{At Longpré}

Height, I8 inches; length, $25^{\frac{1}{2}}$ inches

The village is seen through a road bordered with trees lopped of their lower branches. Signed at the right.

No. I3I

\section{ALFRED STEVENS,}

\section{BELGIUM}

\section{Reverie}

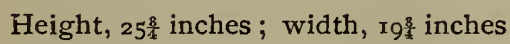

A lady on the seashore, watching the moon rise, with a sadly pensive expression. Signed at the left.

No. 132

CONSTANT TROYON,

FRANCE

\section{Going to Market}

Height, $25 \frac{1}{2}$ inches; width, $2 \frac{1}{2}$ inches

At early morning a woman of the farm is riding to market, mounted on a donkey whose two panniers are filled with fresh vegetables. The road leads her through a field where men and women are already at labor. Signed at the left. 
No. 133

FRITZ VON UHDE, BAVARIA

\section{The Orphans}

Height, $18 \frac{3}{1}$ inches; length, 29 inches

Seated around a table, under a sunlit window, an elder sister, in black, is sewing, while a younger girl knits, and a small boy is industriously preparing his school lessons. Signed at the right.

No. 134

ANTOINE VOLLON,

FRANCE

\section{Study of Still Life}

Height, I8 inches; width, 15 inches

A copper pot, brass dishes, glazed jug, and a glass pitcher. Signed at the left.

No. 135

ALEXANDER H. WYANT, UNited States In the Forest

Height, $\mathrm{I} 6$ inches ; length, 20 inches

From a foreground in deep shade, the eye travels to a lighted opening in the autumnal woods, while the stems of trees in the background are also touched with sunlight. Signed at the right. 
No. 136

JULES BRETON,

FRANCE

\section{Cherry Time}

Height, $x 8$ inches; width, $I_{5}$ inches

A young lady, in a garden orchard which is all abloom with early summer, is plucking cherries from a tree. Signed at the left, I882.

No. 137

JOHN B. BRISTOL,

United States

\section{Shadows upon the Hills}

Height, $x 8$ inches; length, 30 inches

From the foreground, in which appears the figure of a hunter, is viewed the serene expanse of an upland lake, whose farther shore is formed by hills, and whose slopes are flecked with shadows of the flying clouds. Signed at the left.

No. 138

HARRY CHASE,

UNITED STATES

\section{In with the Tide}

Height, I8 inches; length, 28 inches

With the incoming tide, large fishing-boats are entering the Scheldt, in the wake of a steamboat, the distance being enlivened by other vessels. Signed at the right. 
No. 139

ROBERT EICHELBERGER, UNITED STATES

\section{The Road to Sag Harbor}

Height, 20 inches ; length, 27 inches

A sandy Long Island highway, through a level country with stunted trees, in autumn. Signed at the left, $x 889$.

No. 140

ALEXANDER HARRISON, UNITED STATES -

\section{Placid Waters}

Height, 20 inches ; length, 30 inches

On a placid river, which flows between banks, whose foliage bears the tints of early autumn, a woman is seen seated in a boat. Signed at the left.

No. I4I

GEORGE INNESS,

UNited STATES

\section{Indian Summer}

Height, 20 inches ; length, 30 inches

The landscape, which shows the edge of a grove of trees in ripe foliage, basks in the mellow glow of a late afternoon in Indian summer, and is enlivened by a female figure and those of a couple of children. Signed at the left, I886. 
No. 142

LUDWIG KNAUS,

GERMANY

\section{"Excuse Me, Sir"}

Height, 36 inches ; width, $26 \frac{1}{2}$ inches

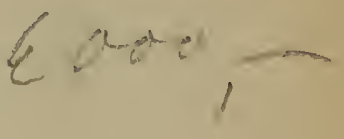

An old bill collector stands in an humble and apologetic attitude, drawing from his wallet the bill which he is to present to the person on whose privacy he has intruded, and whose objections to a settlement he anticipates with an excuse. Signed at the left, I888.

No. 143

HENRI LEROLLE,

FRANCE

\section{The Shepherdess}

Height, $29 \frac{1}{2}$ inches ; width, $28 \frac{8}{4}$ inches

The half-length figure of a French shepherd-girl, wearing a fragment of old blanket for a cloak, watching her flock. Signed at the left.

No. 144

ROBERT C. MINOR,

UNITED STATES

\section{Edge of the Wood}

Height, 30 inches ; width, 22 inches

The termination of the forest shows at the right, in a fringe of tall and stately trees, rocks and a pool of water diversifying the foreground, and an open distance showing under a sky overcast with clouds. 
No. 145

LOUIS METTLING,

HOLLAND

\section{The Snuff-box}

Height, 27 inches; width, 22 inches

The half-length figure of an old woman, holding in her hand a wooden snuff-box from which she has just taken a pinch. Signed at the right.

No. 146

FRANCIS D. MILLET,

UNITED StATES

\section{At the Window}

Height, 24 inches; width, 18 inches

A young lady is reading her favorite book of poems at a window, on whose sill potted flowers make a glow of color in the sunlight which penetrates the apartment. Signed at the left, 1886 .

No. 147

GEORGES MICHEL,

FRANCE

\section{Landscape}

Height, I 8 inches; length, 22 inches

From an elevated foreground extends a vast prospect of country, variegated with undulations, and lighted with gleams of light from the stormy sky. 
No. 148

ANTOINE MAUVE,

HOLLAND

\section{Shelter for the Night}

Height, $15^{\frac{1}{3}}$ inches ; width, $\mathrm{I} 3 \mathrm{f}^{\mathrm{k}}$ inches

At the end of a bleak autumn day, an old shepherd who has brought his flock home from the fields, is drawing them into their stable for the night. Signed at the right.

No. 149

LOUIS METTLING,

HOLLAND

\section{The Cook}

Height, 22 inches ; width, I $6 \frac{1}{2}$ inches

The interior of a dusky Dutch kitchen, with the full length figure of a comely housewife, who brings in her apron and a basket the vegetables which she has gathered in the garden. Signed at the right.

No. 150

GEORGE H. MCCORD, United StATES

Sunset, Isle of Wight

Height, 18 inches; length, 30 inches

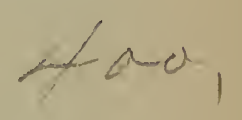


No. 151

GEORG OELDER,

GERMANY

\section{The Farm}

Height, 23 inches; length, $3^{\frac{1}{2}}$ inches

A German farm, with a man and woman at work in the field on the right, and at the left a canal bordered with small trees. Signed at the right.

\section{No. 152}

\section{ALFRED STEVENS,}

BELGIUM

\section{Cupid's Visit}

\section{Height, 26 inches ; width, 199 inches}

A lady is seated in her boudoir with book in hand, which she neglects to read, while Cupid, who has flown in through the open window which overlooks a sunlit garden, leans on a table, and watches her with a roguish expression. Signed at the left, r885.

No. 153

ROMAN RIBERA,

SPAIN

\section{The Squire's Duty}

Height, 22 inches ; width, ${ }_{7} 7$ inches

The squire of some nobleman who has just returned from a long journey is seated before the fireplace in a castle hallway, refreshing himself with pipe and glass, before he enters upon the duty of cleaning up his master's armor and accoutrements which are scattered about. Signed at the right. 
No. I 54

CONSTANT TROYON,

FRANCE

\section{A Coast Pasture}

Height, $x_{4}^{\frac{1}{2}}$ inches ; length, $18 \frac{1}{4}$ inches

Cows on the turfy summit of one of those cliffs which overhang the sea on the Normandy coast. At the right is the roof of a small farmhouse or cabin. The sky is banked up with wind-blown clouds. The picture is signed at the left, and dated on the stretcher, Ist of January, $\mathbf{I} 855$.

No. I 55

ALEXANDER H. WYANT, UNiTed States

Sunset

Height, 16 inches; width, 12 inches

The glow of a deep-toned sunset is reflected on a pool in the foreground, with trees at the right, and the distant landscape obscured by the shadows of the hour. Signed at the left.

No. 156

GEORGE INNESS,

United STATES

\section{The Hillside}

Height, 12 inches; length, 18 inches

A hillside descends from the right of the picture in the foreground. At the left is a grove. The figure of a girl is seen descending the hill. Signed at the right, I886. 
No. 157

JOSEF ISRAELS,

HOLLAND

\section{"Will they Return?"}

Height, $x 5^{\frac{8}{2}}$ inches ; width, $x 2 \frac{8}{\frac{8}{4}}$ inches

A fishing boat has put off to sea on a day which threatens squalls, and the sweetheart of one of the fishermen, sitting on the slope of a sand dune, watches his departure with a face troubled by fears that he may not return. Signed at the right.

No. 158

CHARLES CHAPLIN,

FRANCE

\section{Unmasked}

Height, $x 8$ inches ; width, $\mathrm{I} x \frac{1}{8}$ inches

A half-length of an aristocratic lady in elegant full ball toilette, who has just removed her mask, which she holds in her left hand. Signed at the right.

No. 159

LOUIS DESCHAMPS,

FRANCE

\section{The Cherry Girl}

Height, $x_{7 \frac{1}{4}}$ inches ; width, $x_{3}$ inches

A street vender of cherries, seen at half length. Signed at the right. 
No. 160

CHARLES H. DAVIS,

UNited STATES

\section{Summer Shade}

Height, I2 inches ; length, I8 inches

The yard of an old French farm, whose walls show between the chestnut-trees which occupy the foreground and shade a footpath, while glimmers of full midsummer sunlight are seen on grass and foliage. Dated, 1886.

No. I6I

CARL HEFFNER,

GERMANY

\section{Miniatures}

Height, 8 inches ; length, $23 \frac{1}{2}$ inches

A group of seven miniature landscapes of exquisite execution.

No. 162

T. ECKENFELDER,

BAVARIA

\section{The Village Smithy}

Height, 77 inches ; length, 27 inches

A cartman, whose horse has gone lame from a bad nail in its shoe, has halted at a village smithy in Bavaria to have the nail extracted, and watches the smith while he performs the work. Two other horses await attention, and the cartman's dog is watching the performance. Signed at the right, 1885 . 
No. 163

JULES LEFEBVRE,

PARIS

\section{Sappho}

Height, $21 \frac{1}{2}$ inches ; width, 16 inches

The young poetess shown in profile, at nearly half length, seated and facing towards the right, with a scroll in her hand, and her dark hair crowned with the laurel wreath which her ode has won for her. Signed at the right.

No. 164

ANDREAS ACHENBACH,

GERMANY

\section{After the Storm}

Height, $12 \frac{1}{2}$ inches ; length, $16 \frac{1}{4}$ inches

A terrific gale is blowing, and luggers and fishing-boats are beating into port at some harbor on the North Sea, while a fisherman in dreadnaughts on the shore in the foreground stands ready to lend them whatever assistance he can. Signed at the left, I884.

No. 165

F. K. M. REHN,

United STATES

\section{Salt Marshes}

Height, 12 inches ; length, 18 inches

A strongly colored sunset over salt marshes, traversed by a winding inlet from the sea, in which is a boat. Signed at the right. 
No. 166

ALFRED STEVENS,

BELGIUM

On the Coast

Height, $29 \frac{1}{2}$ inches ; width, 22 inches

Two poor little orphans of some drowned fisherman, a sister and a younger brother, are returning from some weary labor along the shore of the element which orphaned them. Signed at the left, I883.

No. 167

VIRGINIE DEMONT-BRETON,

FRANCE

\section{Gold and Blue}

Height, $30 \frac{1}{2}$ inches; width, 22 inches

A barefooted little girl, with pale golden hair and wearing the dress of the common people in France, is perched on a chair in a cottage kitchen, making her luncheon off a loaf of bread, fragments of which she throws to the little chickens which peck about on the floor. Signed at the right.

No. 168

\section{ALEXANDER HARRISON, UNited STATES}

\section{After Sunset}

Height, 20 inches ; length, 40 inches

A scene on the seashore, with breakers coming in on a strip of strand in the foreground, and the sky flushed by the afterglow of a brilliant sunset. Signed at the left. 
No. 169

WINSLOW HOMER,

United States

\section{Watching the Breakers}

Height, 30 inches ; length, 40 inches

A scene on the New England coast. A savage surf is breaking on a shore of shelving rock. In the foreground two young ladies stand on the safe elevation of a rocky bluff, looking down upon the fury of the waters. Signed at the right, I8gI.

No. 170

GEORGE INNESS,

United States

\section{A Storm on the Delaware River}

Height, 30 inches ; length, 45 inches

The broad stream is seen from an elevated foreground, with farms on the shore at the left and a hilly shore at the right. A timber raft is on the river, and a flatboat is crossing by a rope ferry. A summer rainstorm is blowing off over the water and losing itself in the distance, and a rainbow quivers in the sky. Signed at the left, I8gr.

No. 17 I

GEORGE CLAUSEN, ENGLAND

\section{The Woodcutters}

Height, $39 \frac{1}{4}$ inches ; width, $26 \frac{1}{4}$ inches

An old woodcutter and his boy, returning from their day's work at eventide. Signed at the left, I 885 . 
No. 172

CLAUDE MONET

FRANCE

\section{A River-bank}

Height, $36 \frac{1}{2}$ inches ; width, 29 inches

Along the bank of a stream grow tall poplar trees, lopped according to French custom of their lower branches, the warm gleams of the declining sun coloring their stems. Signed at the left, r89r.

No. 173

T. v. MOLITOR,

BAVARIA

\section{Devotion}

Height, $25^{\frac{1}{4}}$ inches ; length, 33 inches

The interior of a Bavarian village chapel, during service, with a congregation of half a dozen engaged in their devotions. Signed at the left.

No. 174

OTTO VON THOREN,

AUstria

\section{A Summer Storm}

Height, 29 inches; length, 40 inches

A thunder-storm over a meadow where horses have been put to graze. At the left a group of horses and a colt huddle together for shelter under some willow trees. Signed at the right. 
No. 175

MAX WEYL, UNited STATES

\section{The Environs of Washington}

Height, 24 inches ; length, 36 inches

One of the suburban farm districts of the Capitol City, with a boy tending a flock of geese. Signed at the left, r885.

No. 176

ALFRED LEONARD WAHLBERG, SWEDEN Path to the Shore

Height, $39^{\frac{1}{2}}$ inches ; width, 29 inches

A footpath leading through a grove to the shore of a bay, with the water illumined by the bright moon of the north seen through the vista formed by the trees. Signed at the right, 1887.

No. 177

FELIX ZIEM,

FRANCE

\section{Venice}

Height, 27 inches ; length, $4 \mathrm{x}$ inches

An evening scene on the Grand Canal, with the Place of St. Mark and the Doge's Palace at the left. Signed at the left. 
No. 178

\section{J. CLAYTON ADAMS,}

\section{A Yorkshire Wheatfield}

Height, 22 inches ; length, $3^{8}$ inches

The wheatfield, golden with harvest, occupies a hillside rising towards the right. Reapers are at work in the corn, and sheaves of wheat are stacked, with the field flowers which have been cut with them variegating their color. Trees are in the middle plain, and at the background a stretch of fertile country is seen. Signed at the right, 1885 .

No. I 79

H. BOLTON JONES,

UNITED STATES

\section{Early Spring}

Height, $23^{\frac{8}{2}}$ inches ; length, 40 inches

A Jersey brookside, fringed with trees and thickets still bare of foliage, though the meadows show signs of reviving verdure, on a bright, windy March day. Signed at the right.

No. 180

HENDRIK WILLEM MESDAG, HOLLAND

\section{The Fishing Fleet}

Height, $24 \frac{1}{4}$ inches ; length, $5^{\frac{1}{2}}$ inches

A Dutch fishing fleet putting out to sea at morning on the full tide. On the shore the fishwives watch the departure of their husbands and sweethearts. Signed at the right. 
No. 181

JERVIS MCENTEE,

United States

\section{October}

Height, 30 inches ; length, 54 inches

The landscape, with its foliage thinned and colored by an early frost, is seen in the dying light of afternoon, under a sky banked up with clouds threatening snow. Signed at the right, 1865 .

No. 182

L. G. PELOUSE,

FRANCE

\section{Sunset}

Height, 26 inches ; length, $3^{6 \frac{1}{2}}$ inches

The landscape is intersected by a creek, and is darkened by the gathering shadows which follow the descent of the sun. Signed at the right. .

No. 183

ALEXIS HARLAMOFF,

RUSSIA

\section{Hungarian Girl}

Height, $34 \frac{1}{2}$ inches ; width, $20 \frac{1}{2}$ inches

The full-length, standing figure of a Hungarian peasant girl, in the picturesque and brightly colored national costume. Signed at the right. 
No. 184

\section{ARTHUR HAWKSLEY,}

ENGLAND

\section{At Glen Conway}

Height, 16 inches ; length, 24 inches

A scene in the courtyard of a Welsh farm, with a girl in the foreground, carrying water buckets to a piped well, for replenishment. Signed at the left, I882.

No. 185

CHARLES LEROUX,

FRANCE

\section{Landscape}

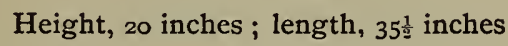

The foreground consists of marshy meadows, with willow trees and bushes, extending to the grassy bank of a broad river, where cattle graze. Beyond the river appear the houses of a large town, apparently the artist $\mathrm{s}$ native city, Nantes. Signed at the left.

No. 186

HENRI LEROLLE,

FRANCE

\section{With the Rising Moon}

Height, 26 inches ; length, 32 inches

Two peasant girls, one mounted on a plough horse while the other walks beside her, are passing through the fields at moonrise, returning from their day's labor. Signed at the right. 
No. 187

H. W. ROBBINS,

UNITED STATES

\section{A New England Highway}

Height, 25 inches ; length, $3^{6}$ inches

A fine broad country road, overshadowed by majestic elm trees in full foliage, with a prospect of Connecticut pastures, farms, and hills in the background, on a bland summer day. Signed at the right, I889.

No. 188

WILLIAM ROELOFS,

HOLLAND

\section{The Riverside}

Height, $19 \frac{1}{2}$ inches ; length, 29 inches

On the bank of a little river, under a clump of willow trees, a woman is washing clothes, while ducks paddle on the water, among lily pads and reeds. Signed at the right.

No. 189

ANTOINE VOLLON,

FRANCE

\section{For the Ball}

Height, $x 4 \frac{1}{\frac{1}{3}}$ inches ; length, 18 inches

Flowers, a fan, and other paraphernalia of a social occasion, on a table. Signed at the right. 
No. 190

JEAN GEORGES VIBERT,

- FRANCE

\section{On the Watch}

Height, I2 inches ; length, $14 \frac{1}{4}$ inches

A huntsman, in antique costume of vivid crimson, is ambushed in a dense forest, and prepares his crossbow for a shot at an approaching stag or boar. Signed at the left.

No. I9I

ALEXANDER H. WYANT, UNited States

\section{A Moorland Sunset}

Height, ro inches; length, $\mathrm{I}_{4}$ inches

The sun has set over a wide moor, leaving but a faint reflection of light in a pool in the foreground. Signed at the right.

No. 192

A. TAMBURINI,

ITALY

\section{Good News}

Height, $\mathrm{ro}_{4}^{\frac{1}{2}}$ inches ; width, 8 inches

An old priest, seated at ease, peruses his morning paper with an expression of satisfaction at the information it conveys. Signed at the left. 
No. 193

MARTIN RICO,

SPAIN

\section{Near Venice}

Height, $7 \frac{1}{2}$ inches ; length, $14 \frac{1}{2}$ inches

The foreground is occupied by the kitchen garden of one of the islands in the lagoon, a portion of the city showing in the distance. Signed at the left.

No, 194

EMILIO SANCHEZ-PERRIER,

SPAIN

\section{The Birches}

Height, $\mathrm{I}_{7} \frac{1}{4}$ inches ; width, 8 inches

A group of birch-trees on the bank of a stream, with boats on the water, under late afternoon effect of summer sunlight. Signed at the right, I886.

No. 195

ANTON MAUVE,

HOLLAND

\section{The Shepherd and His Guard}

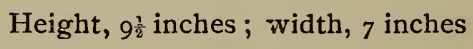

A Dutch shepherd, at evening, seated on a grassy bank, and leaning on his crook, while his faithful dog rests at his knee. Signed at the right. 
No. 196

\section{LEON MORAN,}

UnITED STATES

\section{A Tender Missive}

Height, to inches ; width, 8 inches

A young gallant of the last century, seated at his writing table, is composing a declaration of his feelings to the lady who engrosses them, and whose portrait hangs on the wall. Signed at the left.

No. 197

J. B. JONGKIND,

HOLLAND

\section{Moonlight}

Height, $\mathrm{I}_{3}$ inches ; width, ro inches

The moon is rising in a cloudy sky, and her light flashes upon the ripples of a river in which a large square-rigged vessel and some small boats are seen. At the right are some of the houses of the town, and a quai on which a line of trees is planted. Signed at the left, 1886.

No. 198

ANTOINE VOLLON,

FRANCE

\section{Still Life}

Height, $x_{3}$ inches ; width, $9 \frac{1}{2}$ inches

Upon a table are grouped some scattered articles of jewelry, as if carelessly cast off by their wearer, with a nautilus shell mounted in silver, and a vase with flowers. 
No. 199

JOSEF ISRAELS,

HOLLAND

\section{The Letter}

Height, 12 inches; width, 9 inches

Seated in front of a grate fire in a comfortable apartment, with her feet on a footwarmer, and a letter in her hand, a venerable lady in black considers the contents of the missive. Signed at the right.

No. 200

GUSTAVE JACQUET,

FRANCE

\section{A . Creole}

Height, 18 inches; width, I2 $\frac{1}{2}$ inches

A bust length portrait of a haughty tropical beauty, with a jaguar skin thrown over her left shoulder. Signed at the right.

No. 201

EDMUND HARBURGER,

BAVARIA

\section{The Poet and the Publisher}

Height, ro $\frac{1}{4}$ inches ; length, $13 \frac{1}{\frac{1}{2}}$ inches

The publisher, a type of the human breed which the Germans call the ox, swollen with good living and the vanity of success, is seated at his desk, stupidly listening to the rhapsodies of the lean and shabby poet, a picture of poverty and need, whose manuscript he has carelessly laid upon his knee. One of the most drastic satires of the great Munich satirist. Signed at the left. 
No. 202

EUGENE LE POITEVIN,

FRANCE

\section{Soap-Bubbles}

Height, $\mathrm{r} 6$ inches; width, $\mathrm{x} \mathrm{I}_{\frac{1}{4}}$ inches

A little child, in the outbuilding of a farmhouse, is blowing soap-bubbles and watching some fowl which peck about amid the débris on the ground. Signed at the right, and with the seal of the artist on the back, which probably was attaclied at the time of the sale of his studio effects, after his death in 1870 .

No. 203

\section{ALBERT EDELFELDT,}

FINLAND

\section{The Newest Novel}

Height, 29 inches ; width, $12 \frac{1}{9}$ inches

A lady, seated in her garden, in the shade of an umbrella, beguiles the summer afternoon with a romance of evidently absorbing interest. Signed at the left, I 886.

No. 204

LUIS JIMINEZ,

SPAIN

\section{The Nursling}

Height, 28 inches; width, ${ }_{5} \frac{1}{4}$ inches

A French peasant woman, seated on a grassy bank, looks up from her knitting to watch her nurse child who is playing in the grass. Signed at the left, I887. 
No. 205

JOSEPH WENGLEIN,

BAVARIA

\section{The Coming Storm}

Height, $21 \frac{1}{\frac{1}{2}}$ inches; length, $43 \frac{1}{\frac{1}{3}}$ inches

In the foreground a group of cattle are gathered in a stream under a bank, above which the roof of a farmhouse is seen. The storm is rising over the country at the left. Signed at the right.

No. 206

THOMAS COUTURE,

FRANCE

\section{Italian Woman}

Height, $24 \frac{1}{2}$ inches ; length, $28 \frac{1}{2}$ inches

The head of an Italian model, very solidly and powerfully painted. Signed at the left.

No. 207

CHARLES H. DAVIS,

UNITED STATES

\section{The Herdsman}

\section{Height, 20 inches; length, 27 inches}

A wide, level country, under a bright sky flecked with clouds. On the plain, a herdsman watches his sheep. The foreground is shadowed by the drifting clouds, and the distance is in bright illumination. Signed at the left, I886. 
No. 208

TH. DE BOK,

HOLLAND

\section{Between the Hague and the Sea}

Height, 35 inches; length, 48 inches

A landscape thoroughly characteristic of this district, made famous by Dutch and foreign artists. Signed at the right.

No. 209

GUSTAVE COURBET,

FRANCE

\section{La Source du Lusine}

Height, 40 inches ; length, $59^{\frac{1}{2}}$ inches

The head waters of the River Lusine emerge from a deep gorge or canon of the Vosges Mountains, encompassed by savage cliffs of precipitous rock. The sun has descended below the level of the cliffs, whose shadows darken the stream and render its character more wild and its solitude more strange and sad. The scene is in the artist's native district, where he was fond of seeking subjects and where he found some of his most powerful and grandest inspirations, to the greatest of which this belongs. It was painted in 1875 , and is signed at the right. From the date, it must have been completed by Courbet after his exile to Switzerland, in $187 \mathrm{I}$, for participation in the violences of the Paris Commune. 
No. 2 IO

JAMES TISSOT,

FRANCE

\section{A Parisian Afternoon}

Height, $5^{8}$ inches; width, 40 inches

The garden of the Tuileries, at the time when the band plays and the greatest crowds are attracted. In the foreground an old lady is seated, absorbed in her paper. Her daughter, seated beside her, has put her crochet work back into her portable basket, and laid aside her novel, and is conducting a demure flirtation with a couple of military officers who have halted to observe her. Signed at the left.

No. 2 I I

E. CARPENTIER, FRANCE

\section{The King of the Meadows}

Height, $44 \frac{1}{2}$ inches ; length, $59^{\frac{1}{2}}$ inches

The monarch is a cowboy, who, followed by his dog, marches whistling at the birds. The scene is in bright sunlight. Signed at the left. 


\section{THIRD NIGHT'S SALE}

Friday, February gth

AT CHICKERING HALL

BEGINNING PROMPTLY AT 8 O'CLOCK

No. 212

ARMAND CHARNAY,

FRANCE

\section{In the Garden}

Height, $13 \frac{1}{2}$ inches; length, 19 inches

A lady and a little girl are gathering flowers in the garden of a French country house, accompanied by their pet dog. Signed at the right.

No. 213

\section{CHARLES H. DAVIS, UNited States}

\section{Winter Morning}

Height, 12 $\frac{1}{2}$ inches; length, 18 inches

A frosty winter morning in an apple orchard, with pale sunlight just tingeing the sky, banked up with inclement clouds. Signed at the left, r889. 
No. 2 I 4

ALFRED WIERUSZ KOWALSKI,

POLAND

\section{The Reconnoissance}

Height, 5 inches; length, $6 \frac{1}{2}$ inches

At the edge of a wheatfield, three troop horses are in charge of a trooper who lies stretched at length on the ground, while the officers, who have dismounted, have advanced on foot to make their observations of the movement of the enemy. Signed at the right.

No. 215

JULES DUPRÉ,

FRANCE

\section{Landscape}

Height, $9 \frac{1}{2}$ inches ; length, $\mathrm{I}_{4}$ inches

From a sunny open bank at the left, on which cows are grazing, is seen a stream whose farther shore is shaded by a dense growth of trees. Signed at the left.

No. 216

NARCISSE VIRGILE DIAZ,

FRANCE

\section{Flower Piece}

Height, 6 inches; width, $4 \frac{1}{2}$ inches

A study of flowers in miniature size, extremely rich in color. Signed at the left. 
No. 217

IVAN POKITONOW,

RUSSIA

\section{Autumn, at l'Isle Adam}

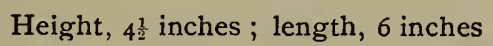

An extensive plain with trees in the middle-ground, under sky filled with broken clouds tipped with light. Signed at the right, 1885 .

No. 218

IVAN POKITONOW,

RUSSIA

\section{A Pool in the Meadow}

Height, $3^{\frac{8}{4}}$ inches : length, 6 inches

The sunlight illumines a pool in the centre, while in the foreground, which is in shade, a sportsman is ambushed among the reeds watching, gun in hand, for the rising of wild-fowl from the pond. Signed at the right, 1886 .

No. 219

EMILIO SANCHEZ-PERRIER,

SPAIN

\section{The Fishermen}

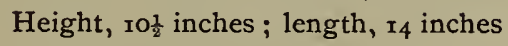

The fishermen are in a boat moored to the bank of a stream which crosses the foreground. Its bank is lined with willow trees, and in the background appear the buildings of a country house. The effect is vivid of midsummer. Signed at the left, I887. 
No. 220

JEAN GEORGES VIBERT,

FRANCE

\section{A New Score}

Height, $3 \frac{1}{2}$ inches ; width, $2 \frac{1}{2}$ inches

An aged cardinal, in the complete scarlet vestments of his ecclesiastical office, is practicing in his private apartments, upon the organ, a new score of his own composition before submitting it for public performance. A wonderful miniature work in character, color, and expression. Signed at the right.

No. 22I

JOSEPH MÉLIN,

FRANCE

\section{Game Overhead}

Height, ro $\frac{1}{2}$ inches; width, $7 \frac{1}{4}$ inches

A dog in the field stands agaze at some bird which flies over its head. Signed at the left, I885.

No. 222

ALEXANDER H. WYANT, UNited States

\section{In the Forest}

Height, 12 inches ; length, 16 inches

An opening in the North Woods, with the foliage in the full richness of summer verdure. Signed at the right. 
No. 223

FELIX ZIEM,

FRANCE

\section{The Lovers}

Height, 14 inches ; width, II inches

At the edge of a wood, a lady and her cavalier, who reclines in the grass, are engaged in conversation, while the splendor of sunset glows in the sky, and colors the waters of a stream in the middle ground. Signed at the right.

No. 224

\section{ALBERT NEUHUYS,}

HOLLAND

\section{Baby's Amusement}

Height, $\mathrm{I}_{3}$ inches; width, $9 \frac{8}{4}$ inches

A baby having become restless in its cradle, the mother has taken it up, and is diverting it by dancing a doll upon a table. The scene is a rural interior in Holland. Signed at the right, I 880 .

No. 225

ANTOINE VOLLON,

FRANCE

\section{Kitchen Still-Life}

Height, $7 \frac{1}{2}$ inches ; length, $19 \frac{1}{2}$ inches

A crockery pot and wine bottle, grouped with part of a pumpkin, some celery, eggs, etc., on a kitchen table. Signed at the left. 
No. 226

BENJAMIN W. LEADER,

ENGLAND

\section{On the Severn}

Height, ro inches : length, $\mathrm{r}_{4}$ inches

A typical English summer landscape with meadow, river, and groves, near the scene of the battle of Worcester, in which King Charles I. received the prophecy of his doom. Signed at the left, $188_{5}$.

No. 227

TH. SALMON,

FRANCE

\section{The Turkey Tender}

Height, I3 inches; width, ro inches

A little peasant girl of the north of France is driving home the flock of turkeys which it is her duty to tend, in order to shelter them from an approaching storm, which already darkens the late afternoon sky. Signed at the left.

No. 228

CARL MARR,

United States

\section{A Mediæval May-Day}

Height, $13 \frac{1}{4}$ inches ; length, $15_{\frac{3}{4}}^{\frac{3}{4}}$ inches

A party of merry-makers from a mediæval German town have come out upon the meadows to celebrate the May festival. The walled town is seen in the distance across the grassy level. Signed at the right. 
No. 229

JULES LEFEBVRE,

FRANCE

Diana

Height, $\mathrm{r}_{3}$ inches ; width, $9 \frac{1}{2}$ inches

A small half length study by the artist for his large full length figure, in this collection. Signed at the left, on top, I885.

No. 230

\section{R. SWAIN GIFFORD, UNited StateS}

\section{A Country Roadside}

Height, $12 \frac{1}{4}$ inches ; length, $19 \frac{1}{2}$ inches

The road is seen from a field in the foreground, crossing the picture beyond a stone fence, a farm wagon passing. Signed at the right.

No. 231

AUGUST VON PETTENKOFEN, AUSTRIA The Pumpkin-Cart

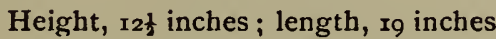

The pumpkin field of a Hungarian farm, with a donkey cart loaded with the fruit of the harvest, and the farmer smoking his pipe as he contemplates its succulent contents. Signed at the left. 
No. 232

R. L. SVOBODA,

\section{An Egyptian Draw-Well}

Height, 12 inches; width, ro inches

In a desert parched by the sun and blazing under its unbroken beams, a well or spring has been dug at which an Egyptian peasant draws water. A few bushes have been nourished by the moisture immediately about the well, but all the rest is parched ground and glowing sky. Signed at the right.

No. 233

CHARLES ÉMILE JACQUE,

FRANCE

\section{Summer}

Height, $16 \frac{1}{4}$ inches ; length, 20 inches

Cattle and sheep are grazing under and around the border of a little grove, watched by a shepherd, while country children are having a picnic in the foreground, The landscape shows the rich foliage and color of midsummer. Signed at the left, I866.

No. 234

JEAN-CHARLES CAZIN,

FRANCE

\section{Autumn}

Height, 18 inches ; width, ${ }_{5}$ inches

The trees in the foreground have been bared by the frost, and their denuded boughs show against a sky colored by the reflection of the sunset. Signed at the left. 
No. 235

GIOVANNI BATTISTA QUADRONE, İTALY

\section{In From the Cold}

Height, I8 inches; width, I2 $\frac{1}{2}$ inches

An old poacher, who has been out in the winter fields, returns to his home with his dogs. He is closing the door of a room whose walls are hung with trophies of dead game. Signed at the left.

No. 236

ANTON MAUVE,

HOLLAND

\section{Ploughing}

Height, 12 inches; length, 25 inches

The field which is darkened by the obscurity of a sky clouded with rain, is being plowed with a primitive Dutch plow, drawn by a team of three horses. Signed at the right.

No. 237

CLAUS MEYER,

BAVARIA

\section{Taking $\mathrm{His}$ Ease}

Height, $\mathrm{x} 6$ inches; width, ${ }_{4} 4$ inches

A young man, in the costume of the seventeenth century, with a red jacket and a broad-rimmed hat, is seen seated at half length at a table in the private room of an inn, with pipe and glass, his head slightly turned as if to greet some person for whom he is waiting. Signed at the left, on top, I886. 
No. 238

ALEXIS HARLAMOFF,

RUSSIA

\section{A Village Beauty}

Height, $20 \frac{8}{4}$ inches ; width, $x 6$ inches

The head of a young Hungarian girl, seen in profile. Very delicate in outline and pure in color. Signed at the right.

No. 239

ALEXANDER H. WyANT, United STATES The Rivulet

Height, $x 6$ inches ; length, 20 inches

A rivulet, through a forest, whose foliage shows autumnal tints and whose middle-ground is in light. Signed at the right.

No. 240

ALFRED STEVENS,

BELGIUM

Ready for the Promenade

Height, $19 \frac{1}{2}$ inches; width, $x_{4} \frac{1}{2}$ inches

A lady standing at a window impatiently awaits the arrival of a tardy escort, to take her upon the promenade. Signed at the left. 
No. 24I

WILLIAM ROELOFS,

HOLLAND

\section{The Bargemen's Breakfast}

Height, I4 inches; length, $2 \mathrm{I}$ inches

A Dutch waterway, with reedy banks, at early morning, showing at the farther shore a barge moored to the bank, on which the men are cooking their breakfast. Signed at the right.

No. 242

CHARLES SPRAGUE PEARCE, United States

\section{Daisies and Corn-flowers}

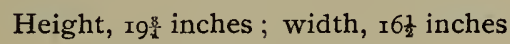

The profile head of a young girl, with her arms full of field-daisies and corn-flowers, is relieved against a background of green foliage splashed with golden sunlight. Signed at the right.

No. 243

GEORGE INNESS,

UNITED STATES

\section{Early Autumn}

Height, I $9_{\frac{3}{x}}^{\frac{3}{x}}$ inches ; length, 30 inches

The middle ground is occupied by trees enriched with autumn tints, among which a house appears, while the foreground, richly carpeted with grass, shows a pool of water at the left. A warm and hazy atmosphere invests the scene. Signed at the left, 1838 . 
No. 244

JEAN PAUL LAURENS,

FRANCE

\section{The Widow}

Height, $24 \frac{1}{2}$ inches; width, I9 inches

The lord of the castle, laid to his last rest in the crypt of the castle chapel, with the death candles burning on the altar in front of which is placed his stone sarcophagus, is visited by his widow, who brings another votive taper to offer for the good of his departed soul. One of the remarkable pictures of mediæval life and manners, for which the artist is famous, and upon which his great reputation is based. Signed at the right.

No. 245

JACQUES MARIS,

HOLLAND

\section{Storm Clouds}

Height, Ig inches ; length, $35^{\frac{1}{2}}$ inches

Over the dune-lands, which lie dark under the shadowed heavens, drives a wild rack of storm clouds, broken by and swirling in the furious blast. Signed at the right.

No. 246

FRITZ VON UHDE,

BAVARIA

\section{The Lost Child}

Height, $25 \frac{1}{2}$ inches ; length, $3 \frac{1}{2}$ inches

The mother has found the lost lamb of the domestic flock, who has strayed away, and is bringing the little girl home through a driving snowstorm. The characters are Bavarian peasants, but the painter has made them, as is his custom, illustrative of a Biblical allegory. Signed at the right, 1892 . 
No. 247

ANTOINE VOLLON,

FRANCE

\section{Study of Still Life}

Height, $25^{\frac{3}{4}}$ inches; length, 32 inches

A freshly boiled lobster, lemons, etc., on a table with a Sévres salad bowl and a copper coffee pot. Signed at the left.

No. 248

\section{CAMILLE HIPPOLTYE DELPHY, FRANCE}

\section{La Seine près Mantes}

Height, 22 inches; length, $3^{8}$ inches

The river occupies the foreground, with clumps of trees on the bank, a village showing on rising ground in the middle plane. The time is early sunset, in autumn. Signed at the right, ISg2.

No. 249

JEAN FRANÇOIS RAFFAELI, FRANCE

\section{L'Ancre}

Height, 27 inches; width, 21 inches

Two old sailors at a bow of a vessel in port, who have secured the anchor to the cathead, are overhauling the chain cable, the port and numerous vessels at moorings showing behind. Signed on the bow of the boat, at the left. 
No. 250

GIUSEPPE BOLDINI,

\section{The Waif}

Height, 22 inches; width, $18 \frac{1}{2}$ inches

The head of a Venetian girl, with a knitted shawl of scarlet worsted. Signed at the right, I883.

No. 25 I

WILLIAM M. CHASE,

UNITED STATES

\section{By the Lake}

Height, 20 inches; length, 24 inches

The terrace and boat landing at Central Park, on a sunny midsummer day, with figures of women and children. Signed at the right.

No. 252

J. B. C. COROT,

FRANCE

\section{Ville d'Avray}

Height, 20 inches ; length, 26 inches

The village where Corot had his country home is in the middle ground at the left, beyond the little lake. In the foreground and at the right is a road upon an elevation, shaded by trees and enlivened with figures. Signed at at the left. 
No. 253

\section{CHARLES FRANÇOIS DAUBIGNY, FRANCE}

\section{On the Marne}

Height, 17 inches; length, $25 \frac{1}{2}$ inches

On the right a low river-bank bears a growth of willows. At the left is a barge. Ducks are swimming in the water. The time is morning, and the period spring. Signed at the right.

No. 254

JULES DUPRÉ,

FRANCE

\section{Windy Weather}

Height, ${ }_{5}$ inches; length, $18 \frac{8}{1}$ inches

The channel sea, with a windy sky full of rolling clouds, and rough water. A fishing-boat is battling with wind and sea, and other boats appear in the distance. Signed the left.

No. 255

EUGẼE FROMENTIN,

FRANCE

\section{The Halt}

Height, $12 \frac{1}{2}$ inches ; length, 16 inches

A bivouac of Arabs in a grove under a hill, on which are the ruined buildings of an old fortress. They have unsaddled, and their tired horses graze about while the masters stretch out at their ease. Signed at the right. 
No. 256

JULES DUPRÉ,

FRANCE

\section{The Farmyard}

Height, $x_{3}$ inches ; length, $16 \frac{1}{2}$ inches

The back yard of a humble French farm, with an old woman going in at the kitchen door. Signed at the left.

No. 257

ALEXANDRE GABRIEL DECAMPS, FRANCE

\section{Le Chenil}

Height, $7 \frac{1}{2}$ inches ; length, $9 \frac{1}{2}$ inches

A kennel of French beagles with the two old dogs of the pack in the foreground, waiting at the feed trough for the huntsman to bring them their meal. From the Laurent-Richard sale, 1878 . Signed at the left.

No. 258

THEODORE ROUSSEAU,

FRANCE

\section{Le Petit Pont}

Height, $6 \frac{1}{2}$ inches ; length, I2 inches

A small stone bridge on arches crosses a-little river, in which horses are being brought to drink. At the right a village shows among trees. The sky is warmed by a tender golden sunset, with clouds suggestive of showers. From the Collection Bellini, exhibited at the Exposition Universelle de l'Art Français, r889. Signed at the left. 
No. 259

EUGENE DELACROIX,

FRANCE

\section{Lion Devouring a Goat}

Height, ro inches; length, $x_{4}$ inches

In the sombre depths of a tropical forest a massive lion is making a ferocious meal off a goat which it has carried off to its lair. In spite of its savage satisfaction in the feast, the huge beast preserves an air of watchfulness, as if anticipating interruption. In powerful color, fierce spirit, and the vivid suggestion of actuality, this picture is one of the finest possible examples of the artist's triumphs in this special line, of which he was especially fond on account of its ferocious picturesqueness of suggestiveness. Signed at the left.

No. 260

ANTOINE VOLLON,

FRANCE

\section{Kitchen Utensils}

Height, $10 \frac{1}{3}$ inches ; length, $18 \frac{?}{2}$ inches

A composition of a glazed jug, brass and copper utensils, eggs in a dish, onions, mussels, etc., affording a singularly rich and varied play of color and sparkle of light. Signed at the right.

No. $26 \mathrm{I}$

ALEXANDER H. WYANT, United STATES

\section{Sunset Gold and Crimson}

Height, 16 inches; width, 12 inches

The waters of a brook, with trees on either bank, intersect the foreground, and catch a reflection of the crimson and gold of the rich sunset sky. Signed at the left. 
No. 262

JULES VEYRASSAT,

FRANCE

\section{The Barge Horses}

Height, $\mathrm{IO}_{2}^{\frac{1}{2}}$ inches; length, $\mathrm{I}_{4}$ inches

A white and a brown barge horse stand on the towingpath of a wide French river, awaiting the arrival of the freight boats for which they are to serve as relays, and tow farther towards their destination. Signed at the right.

No. 263

JOHAN BARTHOLD JONGKIND, HOLLAND

\section{Le Palais Ducal a Nevers}

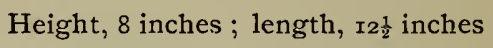

A view of the lofty ducal palace across the marketplace of the town, with a diligence at the door of an inn at the left. Signed at the left, I87I.

No. 264

IVAN POKITONOW,

RUSSIA

\section{L'Eglise de Lons, près Paris}

Height, $6 \frac{1}{2}$ inches; length, I I inches

The church is seen in the middle-ground, with the houses of a village, under a sky with fleecy cloud banks in bright light. Figures of peasants are employed in the field in the foreground. Signed at the right. 
No. 265

J. DAVID DE SAUZEA,

SPAIN

\section{Napoleon on the Isle of Elba}

Height, $3_{\frac{1}{2}}^{\frac{1}{2}}$ inches; length, $6 \frac{1}{4}$ inches

The exiled emperor stands on the beach, leaning against the shattered wreck of a fishing-boat, and gazing out upon the sea. Signed at the left, I 885 .

No. 266

IVAN POKITONOW,

RUSSIA

\section{Chasseur au Marais}

Height, $6 \frac{1}{2}$ inches; length, Ir inches

Hunters are pursuing wild fowl, in one of the vast swamplands of southern Russia, one in the foreground, with a double-barrelled fowling piece, watching for a duck to rise out of the reeds. Signed at the right.

No. 267

FRANCIS D. MILLET, UNited STATES

\section{A Handmaiden}

Height, 27 inches ; width, $x 6 \frac{1}{2}$ inches

The half length figure of a Greek girl, carrying an amphora on her shoulder. Signed at the left, I 886. 
No. 268.

ANTOINE VOLLON,

FRANCE

\section{Vue de Paris}

Height, 18 inches ; length, $2 \mathrm{I}$ inches

A scene on the Seine, at the point where the island of the city divides the river into two arms. From the Coquelin Collection. Signed at the left.

No. 269

HENRI HARPIGNIES,

FRANCE

\section{Edge of the Wood; Sunset}

Height, I9 $\frac{1}{1}$ inches ; length, 24 inches

A little stream, bordered with a rank growth of rushes, makes a winding course between banks upon which trees denote the outskirts of a forest. A pale sunset is splashed with clouds crimsoned by the reflection of the sun, which has passed under the horizon. Signed at the left, I882.

No. 270

ALEXANDER HARRISON, UNITED STATES

Moonrise

Height, 26 inches ; length, 32 inches

A full moon rising in a cloudless sky, over an expanse of quiet sea. Signed at the left. 
No. $27 \mathrm{I}$

\section{GEORGE INNESS,}

United States

\section{The Storm}

Height, 20 inches; length, 30 inches

The sky is driving in clouds swollen and dark with storm. A furious wind twists and bends the trees on a stony hillside at the right, and scatters their foliage before it. In a hollow, in the middle ground at the left, is a house. The broken light lends a wan gleanı to the first scene of a powerful drama of nature. Signed at the right, 1885 .

No. 272

JOSEF ISRAELS,

HOLLAND

\section{When One Grows Old}

Height, ${ }_{3} 6$ inches ; width, 24 inches

The figure of an old Dutch peasant woman seated on a stool, and huddled over a kitchen fire of smouldering turf, at which she endeavors to warm her hands, trembling with the feebleness of advanced age. Signed at the right.

No. 273

GEORGE INNESS,

United States

\section{Tenafly Oaks, Autumn}

Height, 30 inches; length, 45 inches

The oaks, splendid in the livery of autumn, are in the middle ground, in full light, their rich color contrasted with the vivid green of an apple-tree in the foreground, which is in shade. Signed at the left, r8g2. 
No. 274

RAIMUNDO DE MADRAZO,

SPAIN

\section{The Appointment}

Height, $37^{\frac{1}{2}}$ inches; width, $22 \frac{1}{2}$ inches

A lady, in the costume of the Directory period, awaits in a park the arrival of an admirer, whose note of appointment she holds in her hand. Signed at the right.

No. 275

CLAUDE MONET

FRANCE

\section{Above the Sea}

Height, 24 inches; length, $32 \frac{1}{\text { inches }}$

From an elevation on the summit of high cliffs which forms the foreground, and at the left of which is a cabin, the eye overlooks the sea, in which are boats under sail. Signed at the right, I 882 .

No. 276

JOSEPH MELIN,

FRANCE

\section{The Prize}

Height, 32 inches ; width, 22 inches

A setter dog, having captured a partridge which its master has shot, stands with the prize in its mouth, awaiting the coming up of the sportsman. Signed at the left, I886. 
No. 277

GEORGE INNESS,

UNITED STATES

\section{A Spring Morning}

Height, 30 inches ; length, 45 inches

A clear, cool morning in spring, the tender green of the landscape seen in an atmosphere of delicate grays. The foreground is a richly grassed meadow, divided by a creek, and in shade from a passing cloud, the light falling across the distance. An elm-tree is in the middle ground. Signed at the left, 1892 .

No. 278

JEAN FRANÇOIS MILLET,

FRANCE

\section{Le Bucheron}

Height, 32 inches ; width, $28 \frac{1}{2}$ inches

At the end of a bitter autumn day, a peasant, who has been sawing fire-wood in an old park, is breaking the last stubborn and knotty billets up with wedges which he drives home with a ponderous mallet. His figure shows the exhaustion consequent upon a long day of severe toil ; and the intense action of his powerful frame, and the fierce expression upon his face reveal the determination to complete his task before night shall close in. Signed at the right. 
No. 279

CONSTANT TROYON,

FRANCE

\section{Renard pris du piege}

Height, 34 inches ; width, 27 inches

An old fox has had his prowlings terminated by getting one of his forepaws caught in a steel trap. He raises his head, howling in mingled fury, pain and despair, while his body is convulsed by throes of anguish. The background is rich summer foliage. A most powerful work in drawing, color, and handling. From the Otlett Collection, Brussels. Signed at the left.

No. 280

NARCISSE VIRGILE DIAZ,

FRANCE

\section{Edge of the Wood: Fontainebleau}

Height, $23^{\frac{1}{4}}$ inches ; length, $33^{\frac{7}{3}}$ inches

The outskirt of the forest, with scattering trees, in autumn, and under a clouded sky. Signed at the left, I87i.

No. $28 \mathrm{I}$

\section{CHARLES FRANÇOIS DAUBIGNY, FRANCE}

\section{A Village on the Marne}

Height, ${ }^{3 \frac{8}{4}}$ inches ; length, $26 \frac{1}{4}$ inches

The houses of a village make a line along the top of a sloping river bank at the right. On the margin of the river, women are washing clothes, and a man waters horses. Ducks are in the water, which reflects the warm color of an afternoon sky. Signed at the right, x 860 . 
No. 282

FELIX ZIEM,

FRANCE

\section{Bords du Rhone}

Height, ${ }_{17}$ inches; length, 28 inches

The river bank is lined with birch trees, tinted with the colors of early autumn, and warmed by a late afternoon sky. Signed at the left.

No. 283

JOHAN BARTHOLD JONGKIND, HOLLAND

\section{Grand Route}

Height, $16 \frac{1}{2}$ inches ; length, 22 inches

The highway is lined with houses at the right, a huge farm wagon and a post carriage appearing in the road. The descent of a hillside at the left reveals a glimpse of distant country, under a sky overcast with rain-clouds which are broken with gleams of sunset. Signed at the left.

No. 284

LOUIS DESCHAMPS,

FRANCE

\section{The Street Player}

Height, 23 inches ; width, $15 \frac{1}{2}$ inches

The half length figure of a girl with an accordion. Signed at the right. 
No. 285

LUDWIG ${ }^{\top}$ KNAUS,

GERMANY

The Coffee-Hour

Height, 26 inches ; width, $18 \frac{8}{8}$ inches

The coffee-hour in Germany is a period of the day when people who have been working in the morning refresh themselves before their dinner, in order to be able to do still more work in the interval. Seated beside a warm stove in his humble lodgings, a poor music copyist, or scrivener of some sort, sips at his hot cup, with his eye on the clock, so as to be sure that he shall not miss his next appointment. Signed at the left, I874.

No. 286

WILLIAM ROELOFS,

HOLLAND

\section{In Holland}

Height, $18 \frac{1}{2}$ inches ; length, $29 \frac{1}{2}$ inches

At the edge of an extensive pasture, watered by a creek, is seen a peasant's hut, with a female figure, while cattle graze in the meadows. Signed at the left.

No. 287

ALFRED STEVENS,

BELGIUM

\section{Meditation}

Height, 29 inches ; width, $18 \frac{1}{2}$ inches

A lady, absorbed in reverie, leans upon the railing of a garden overlooking a moonlit sea, with her little dog on the garden seat for companion. Signed at the right. 
No. 288

ANTOINE VOLLON,

FRANCE

\section{A Corner of the Kitchen}

Height, $16 \frac{1}{4}$ inches; width, $12 \frac{8}{4}$ inches

An arrangement of culinary still life, in an angle of a kitchen wall. Signed at the right.

No. 289

I. VAN POKITONOW,

RUSSIA

\section{Glimpse of Switzerland}

Height, 6 inches ; length, ro $\frac{1}{2}$ inches

The foreground is the crown of a grassy hill, with the barn of a mountain farm showing at the left, and in the distance at the right the summits of mountains patched with snow. Signed at the right.

No. 290

EUGENE L. G. ISABEY, FRANCE

\section{Royal Guests in a Convent}

Height, $9 \frac{1}{2}$ inches; length, $1_{3}$ inches

A regal hunting party is being feasted after the chase in the great hall of a Gothic convent. Signed at the right, 1875 . 
No. 291

GEORGE H. BOUGHTON,

ENGLAND

\section{The Judgment of Wouter Van Twiller}

Height, $2 \mathrm{I}_{\frac{1}{2}}$ inches ; length, $30 \frac{1}{2}$ inches

In Chapter I. of Book III. of " Knickerbocker's History of New York," we are informed how that wise magistrate Wouter Van Twiller decided the lawsuit between Wandle Schoonhoven and Barent Bleeker, who had fallen out over their respective accounts, each claiming that the other owed him money. So the sage Van Twiller ordered each to bring his account book to him, when, having weighed them in his hands and counted the leaves, he announced that he had found each book to be as thick and heavy as the other, and that, therefore, neither owed the other anything, so that "Wandle should give Barent a receipt, and Barent should give Wandle a receipt, and the constable should pay the costs." This is the scene which the artist illustrates with a humor equal to that of the author himself. The picture was painted in 1876 , and is signed at the left.

No. $29^{2}$

WILLIAM M. CHASE,

UNITED States

\section{In the Studio}

Height, 39 inches ; width, 221 inches

A lady in white seated in an armchair in an elegantly furnished studio, the wall of which is set off with pictures; draperies, and a shelf arranged with curious bric-à-brac. Signed at the left. Pastel. 
No. 293

GEORGE INNESS,

UNITED STATES

\section{Sundown at Montclair}

Height, 30 inches; length, 45 inches

The rich glow of sunset flushes the sky behind an elm tree which rises in the centre of the picture, a portion of a farmhouse is seen at the right, and the foreground is a grassy field crossed by a stone wall. The time is midsummer. Signed at the right, 1892 .

No. 294

\section{ALEXANDER HARRISON, UNITED STATES}

\section{Le Soir}

Height, 27 inches; length, 47 inches

The dusk of evening glooms a stream, embowered by trees, which traverses the picture from left to right, the last pale light of sunset showing through breaks of the boughs and foliage.

No. 295

JULES DUPRÉ,

FRANCE

\section{Le Vieux Chéne}

Height, $4 \mathrm{I}$ inches; width, 40 inches

A clearing in the forest, showing at the right, in the middle-plane, a herdsman's cottage. In the centre foreground is an old oak tree, under which some cattle repose. The landscape is warmed by the mellow glow of evening. From the Dupré sale. Signed at the left. 
No. 296

CONSTANT TROYON,

FRANCE

\section{Ewe and Lamb}

Height, 45 inches; width, 35 inches

In the foreground of a pasture field, a fine ewe watches over her lamb, which presses conifidingly to its mother. Other sheep and cattle are in the background, and at the right the shepherd stands guard over his flock. The color is mellow with summer warmth. Signed at the left.

No. 297

GUSTAVE COURBET,

FRANCE

\section{The Rising Sea}

Height, 32 inches ; length, $39 \frac{1}{2}$ inches

A storm is blowing up the English Channel. A bank of clouds, sullen and dark with the portent of sulphurous storm, is driving across the sky. A fishing boat, warned by the forerunners of the tempest, is speeding towards its harbor. In the foreground, the sea, rising, but not yet iri its terrific fury, breaks in massive rollers over the shallows of the shore, making a stern threat of what is yet to come out of the wrath of the elements. Courbet's fierce and contentious spirit inspired him to some magnificent pictures of the sea, always in times of storm. He worked in these moods in a glass-windowed shed so close to the waves that the salt spray left an incrustation on the panes. His great picture, "The Wave," is one of the most stirring modern works in the national collection of France, and all of his sea-pieces are justly ranked among his most exemplary works. Signed at the left. 
No. 298

GEORGE INNESS, UNited STATES

\section{A September Breeze}

Height, 30 inches; length, 45 inches

Cattle are grazing in the foreground. In the middle plane are oak and maple trees, rich in autumnal foliage, blown by the breeze ; houses showing in the background. Signed at the left, I 892 .

No. 299

ALFRED STEVENS,

BELGIUM

\section{The Departure}

Height, $36 \frac{1}{2}$ inches ; width, 29 inches

A lady in a summer costume of red and white stands on the beach, looking out to sea, and following a receding ship with an intent expression. At the right, figures are seated on a breakwater, which has been left bare by the receding tide. Signed at the left, Havre, I884.

No. 300

RICHARD PAULI

\section{United STATES}

\section{At Sunset}

Height, 24 inches; length, 40 inches

On the bank of a broad river, farm buildings are seen under tall trees, in the modified light of a late summer sunset. Signed at the left, I8go. 
No. 301

FRITZ VON UHDE,

BAVARIA

\section{The Road to Bethlehem}

\section{Height, 26 inches ; length, $3^{1 \frac{8}{4}}$ inches}

A poor carpenter, with his wife beside him, trudges along a village road on a murky winter day. The figures are those of modern German working people, and the surroundings are distinctly those of the Bavaria of the day, but the artist adheres to his practice of attaching a biblical significance to a scene from ordinary life. Signed at the right.

No. 302

CHARLES SPRAGUE PEARCE, UNITED STATES

\section{Going to Work}

Height, 29 inches ; width, $23 \frac{8}{3}$ inches

On a bright spring morning a French peasant girl is going to the fields, carrying on her shoulder a crescentshaped bill-hook on a long pole, which is used in lopping off the lower branches of trees. Signed at the right.

No. 303

ALFRED LEONARD WAHLBERG, SWEDEN The Landing Place

Height, $20^{3}$ inches; length, 32 inches

The entrance to a Swedish fishing post, with a lighthouse in the distance, and in the foreground a landing stage at which a boat is coming up, seen under bright moonlight. Signed at the left, 1887 . 
No. 304

HENRY W. RANGER,

United States

\section{Dutch Landscape}

Height, 18 inches; length, 28 inches

Under a windy sky extends a wide distance of the level lands peculiar to central Holland, with a windmill in the middle ground, and a woman and child on the road at the right. Signed at the left, 1887 .

No. 305

THOMAS W. WOOD,

United States

\section{The Quack Doctor}

Height, 28 inches; length, 40 inches

fn itinerant charlatan has halted his wagon in the main street of a village, where he demonstrates the use of his nostrums upon a native victim, to the admiration of the assembled population. Signed at the left, I882.

No. 306

HENRI LEROLLE,

FRANCE

\section{The Potato Harvest}

Height, $39 \frac{1}{2}$ inches ; length, $39 \frac{1}{2}$ inches

A field upon a hillside, which descends towards the right, has been harvested, and a woman passes down it, bent by the burden of a sack of potatoes on her back. On the hilltop a fire is burning, and crows fly in the evening air. Signed at the right. 
No. 307

D. RIDGWAY KNIGHT,

UNITED STATES

\section{The Last Rose}

Height, $45^{\frac{1}{2}}$ inches; width, $32 \frac{1}{4}$ inches

A French country girl, in the garden of a farm, who clips from the rose bushes the last of the flowers which the season permits them to bear. Signed at the right.

No. 308

C. BISCHOF,

\section{Portrait of a Girl}

Height, $37^{\frac{8}{2}}$ inches; width, $2 \mathrm{I}_{2}^{\frac{1}{2}}$ inches

The portrait of a young girl, at half length, with her left hand at her breast, painted boldly and solidly, with deep harmony of color and strong Rembrandtesque effect. Signed at the left.

No. 309

ADOLPHE ARTZ,

HOLLAND

\section{Gleaners of the Shore}

Height, 25 inches; length, 54 inches

Women and children of a Dutch fishing village, who have been gathering shellfish along the shore, are returning homeward on a breezy afternoon when the rising tide has put an end to their work. Signed at the right. 
No. 3 IO

\section{CHRISTIAN MALI,}

\section{The Shepherd's Breakfast}

Height, $35^{\frac{1}{2}}$ inches; length, 63 inches

Seated at the door of his sheep-stable, the shepherd is concluding his frugal morning meal, while his dog appeals to him for a share, and the patient flock huddles around him, with longing glances toward the fresh, bright morning which shows at the open entrance. Signed at the right, I88o.

No. 3 I I

L. NEUBERT,

GERMANY

\section{Landscape}

Height, $39^{\frac{1}{2}}$ inches ; length, $6_{3}$ inches

A hillside foreground, with trees at the right, overlooks an extensive plain under an autumnal sky. Signed at the right.

No. 312 .

\section{ARTHUR PARTON, UNITED States}

\section{Evening after the Rain}

Height, $5^{\circ}$ inches; length, 60 inches

Awarded one of ten gold medals of honor, contributed by the American Art Association at their Second Annual Competitive Prize Fund Exhibition, New York, 1886. Medals awarded by vote of the Artist Exhibitors. 
No. 313

OTTO VON THOREN,

FRANCE

\section{Share and Share Alike}

Height, 40 inches ; width, 32 inches

An aged shepherd, standing in a field, with the wheeled hut in which he sleeps as he follows his sheep from pasture to pasture, near by, is enjoying his evening meal of bread and cheese, while his two dogs patiently and mutely supplicate him for their share of the rations.

No. 314

CARL MARR,

UNITED STATES

\section{Peace and War}

Height, 42 inches ; length, $66 \frac{1}{2}$ inches

A shepherd is seated on the ground at the right, while his flock graze around him, in a spring landscape smiling with peace. In the middle ground a knight in complete armor rides by on his way to battle. Signed at the right, I 886 .

No. 315

\section{ALBERT NEUHUYS,}

HOLLAND

\section{The Seed Bowl}

Height, $53^{\frac{1}{2}}$ inches ; width, $40_{\frac{1}{2}}^{\frac{1}{2}}$ inches

Seated in a kitchen garden, with a hedge and trees in the background, a gardener scrapes plant-seed into a wooden bowl, while two little children watch him. Signed at the right. 


\section{CONCLUDING SALE}

WATER COLORS, ENGRAVINGS, ETCHINGS, DRAWINGS IN

\section{BLACK AND WHITE}

To be Sold on Saturday Afternoon, February Ioth

BEGINNING PROMPTLY AT 3 O'CLOCK

AT THE AMERICAN ART GALLERIES

No. 316

Sur la Route en Hiver, Artois

Height, II i⿱ inches; length, I8 inches

Braun photograph, from the original picture by Jules Breton. Signed by the artist, I884.

No. 3 I7

\section{The Communicants}

Height, $I I_{4}^{\frac{1}{4}}$ inches ; length, ${ }^{7} 7_{\frac{3}{4}}$ inches

Braun photograph, from the original picture by Jules Breton. Signed by the artist. Original painting in the collection of Sir Donald A. Smith, Montreal, Canada. 
No. 318

\section{Christ and the Rich Young Man}

Height, 21 inches; length, $27 \frac{1}{2}$ inches

Photogravure, from the original picture by J. M. H. Hofmann. Proof, signed by the artist.

No. 319

\section{The Helping Hand}

Height, 18 inches; length, 26 inches

Photogravure, relieved by etching, after the original painting by E. Renouf. An old fisherman in his boat, whose little grand-daughter plays at lending him a hand at the oar. Artist's proof. Original painting in the Corcoran Gallery of Art, Washington, D.C.

No. 320

CARL MARR,

UNiTED STATES

\section{Drawing}

Height, 20 inches; width, I2 inches -

The original design in black and white for the invitation to the Anglo-American ball, given at the Bayerischer Hof, in Munich, by artists of those nations, on St. Valentine's Day, 1887. Signed at the right. 
No. $32 \mathrm{I}$

GEORGES BRILLOUIN,

FRANCE

\section{No Luck}

Height, 22 inches; width, $16 \frac{1}{2}$ inches

An old sportsman, after a bad day in the fields, is endeavoring to drive away his melancholy at a wayside inn with bottle and glass. Signed at the left. Charcoal drawing.

No. 322

LÉON AUGUSTIN L'HERMITTE, FRANCE

\section{Interieur de Paysans}

Height, I 2 inches ; length, I 7 inches

The kitchen of a peasant's house, with the master regaling himself with a tumbler of wine after his labor in the vineyard, and chatting with one of the women of the house. Signed at the right. Charcoal drawing.

No. 323

\section{LEON AUGUSTIN L'HERMITTE, FRANCE}

\section{Eglise de Village}

\section{Height, 18 inches; width, I4 inches}

The interior of a French provincial church, with a lady at her devotions in the foreground, and a peasant woman bringing her children in to worship. Signed at the left. Charcoal drawing. 
No. 324

THURE DE THULSTRUP,

SWEDEN

\section{A Relay on the Old Boston Post Road}

Height, 17 inches ; length, 24 inches

A stage-coach has drawn up at a relay house on the old post road between New York City and Boston to change horses, and the people of the tavern are welcoming the guests. Signed at the left, 1886. Drawing in black and white gouache.

No. 325

CARL MARR,

UNITED STATES

\section{The Lovers}

Height, 25 inches ; width, 17 inches

Two lovers engaged in conversation form the picture, to which is provided a decorative setting. Signed at the right. Drawing in black and white.

No. 326

A. B. FROST,

UNITED STATES

\section{In Luck}

Height, $32 \frac{1}{2}$ inches ; length, 40 inches

An old darky, who has been foraging in the woods, is returning with a fine wild turkey, which he has brought down for his Christmas dinner. Signed at the left. Drawing in black and white gouache. 


\section{ETCHINGS}

No. 327

\section{The Cast Shoe}

Height, $16 \frac{1}{2}$ inches ; length, $23 \frac{1}{2}$ inches

Etching by Robert W. Macheth. Artist proof impression. Macbeth is a son of the Scotch portrait painter Norman Macbeth, and was born at Glasgow in I 848. He studied art at the Royal Scottish Academy schools there, and commenced to exhibit pictures in oil and water colors in 1870 . Experiments in etching eventually inclined him to the extensive practice of that art, both with original subjects and reproductions, and he holds an unrivalled place to-day among the etchers of England.

No. 328

\section{Charles Darwin}

Height, 22 inches ; width, 16 inches

Etched by Paul Rajon, after the original portrait by W. W. Onless, R. A. One of the earliest proofs, with eight heads in remark on the margin. This is one of the most highly esteemed of the etcher's plates. Rajon was the son of a barber and hairdresser at Dijon. He obtained employment with a photographer in Paris as retoucher, studied painting under Pils and etching under Bracquemond. He worked in London and New York, and returning to Paris from this city after a second visit to the United States, died of pneumonia in I888. This portrait of Darwin won the etcher a medal at the Universal Exposition of 1878 . 
No. 329

\section{The Grafter}

Height, $18 \frac{1}{2}$ inches ; length, $2 \mathrm{O}_{2}^{1}$ inches

Etched by Victor Focillon after the original picture by Jean François Millet. Remark proof. Focillon was born at Dijon, and is a graduate of the School of Fine Arts of that city. He has acquired especial distinction for his reproduction of the pictures of Millet and the other great painters of that school, in which he preserves the handling and sentiment of the originals, as well as the form and composition.

No. 330

\section{The Children of the Sea}

Height, $\simeq 6 \frac{1}{2}$ inches ; length, 27 inches

Etched by Carel L. Dake, after the original painting by Josef Israels. Artist's proof, signed by painter and etcher. Dake was born in Amsterdam, in 1857 , and was a student in the studio of Charles Verlat in Antwerp. His work as an etcher ranks him as the most original and advanced technician in the Low Countries, and among the first living. $\mathrm{He}$ is a professor of the Antwerp Academy of Fine Arts, and for ten years, while experimenting in etchings, was granted a pension by the late King William III. This picture, which is among his most highly esteemed plates, represents the little children of a fisherman, who, having made a toy boat out of an old wooden shoe, are sailing it in the wash of the breakers on the sea-shore. 
No. 33I

\section{After Rain}

Height, ${ }_{5}$ inches; length, 25 inches

Artist etching by Henry Charles Fox, of London. Remark proof. This artist is a workman in the school of the late B. W. Leader, and is well known as a painter and draughtsman, as well as a daring experimentalist in the possibilities of artistic etching, with invariably powerful results.

No. 332

\section{Murtly Moss}

Height, 16 inches; length, 25 inches

Artist's proof etching, two signatures, by A. BrunetDebaines, after the original picture by Sir J. E. Millais. Alfred Brunet-Debaines is the son of an architect, born at Havre in 1845 . He studied painting at the Paris École des Beaux Arts, and under Pils, and then practised etching under Lalaune, Gaucherel, and Normand. He is not only widely known as an artist-etcher, but also for his remarkable reproductions of the works of other artists, made in France and during a long sojourn in England. 
No. 333

\section{Christ before Pilate}

Height, 25 inches; width, $35^{\frac{1}{2}}$ inches

Proof of the etching by. Charles Waltner, from the original picture by M. Munkacsy, with remark portraits of artist and etcher, and signed by both. Original painting in the collection of the Hon. John Wanamaker, Philadelphia, Penn. Waltner was born in Paris in 1847 , and was a pupil of Martinet, and Henrique Dupont in engraving, and of painting under J. L. Gérôme. He eventually adopted etching, and in I869 won the Prix de Rome at the Salon. His plates after "The Angelus" of Millet, "The Night Watch" of Rembrandt, Gainsborough's "Blue Boy," etc., are famous wherever engravings are known. He is a chevalier of the Legion of Honor and a member of the Société Nationale des Beaux Arts.

No. 333 "A"

\section{Christ before Pilate}

Same as No. 333 above described.

No. 334

\section{Windsor}

Height, $17 \frac{3}{4}$ inches; length, 25 inches

Etched by A. Brunet-Debaines, after the picture by Karl Heffner. Artist's proof. A scene on the upper Thames, with the river in the foreground embowered with verdure. Windsor Castle showing in the distance. 
No. 335

\section{Evening Glow}

Height, $20_{\frac{1}{4}}^{\frac{\pi}{4}}$ inches ; width, ${ }_{5}$ inches

Etched by Théophile Chauvel, after the picture by Karl Heffner. Artist's proof. Chauvel was born in Paris in I83r. He studied under Aligny and Picot, and became well known as a landscape painter, first exhibiting at the Salon of 1855 . In 1867 he commenced to exhibit as an etcher, and in 1870 as a lithographer, and in 1873 he practically gave himself up to etching, though he still paints and lithographs upon occasion. He is recognized as one of the leading landscape etchers of the French school; is a Chevalier of the Legion of Honor, President of the Society of French Etchers, and was awarded the Salon Medal of Honor I88I, for his plate after Corot, "The Willow Bank."

No. 336

\section{The Hamlet}

Height, $9 \frac{1}{2}$ inches; length, $x 2$ inches

Artist etching by Georges Antonin Lopisgich. Remark proof on parchment. Lopisgich was born at Vichy in I854. He is a pupil of Bonnat, Le Roux, and Le Couteux, and is recognized as a painter as well as an etcher. This plate is esteemed his finest original work. It is in pure dry-point, extremely brilliant and rich in color.

No. 337

\section{Ville d'Avray}

Height, $14 \frac{1}{x}$ inches ; length, 22 inches

Etched by Th. Chauvel, from the painting by J. B. C. Corot. The artist's country home, outside of Paris. Parchment proof, in the first state. 
No. 338

\section{The Water Mill}

Height, 16 inches; length, $2 x$ inches

Etched by A. Brunet-Debaines, from the original picture by John Constable, in the British National Gallery. Artist's proof.

No. 339

\section{L'Angelus}

Height, 21 inches ; length, 25 inches

Etched by Charles Waltner from the painting by Jean François Millet. Remark proof ; the remark, a portrait of Millet. This proof is from the second large plate of this subject, etched by Waltner. Published by subscription, and edition limited to one hundred impressions. Plate destroyed and fragments distributed to subscribers.

No. 340

\section{Lingering Autumn}

Height, $18 \frac{1}{2}$ inches ; length, $28 \frac{8}{4}$ inches

Etched by Theophile Chauvel, after the picture by Sir J. E. Millais, R, A. Artist's proof. 
No. 34 I

\section{Bacchus and Ariadne}

Height, $24 \frac{1}{3}$ inches; length, $27 \frac{1}{4}$ inches

Etched by Robert W. Macbeth, after the painting by Titian. First state proof. Printed and signed by Goulding.

No. 342

\section{The Hay Wagon}

Height, ${ }^{7} 7 \frac{8}{x}$ inches ; length, $24 \frac{1}{4}$ inches

Etched by A. Brunet-Debaines, after the picture by John Constable, R. A. Artist's proof. The original painting in the British National Gallery.

No. 343

\section{Still Waters}

Height, ${ }^{7} 7^{\frac{8}{4}}$ inches ; length, $28 \frac{1}{4}$ inches

Etched by Theophile Chauvel, after the painting by Karl Heffner. Artist's proof. 
No. 344

\section{Great Marlowe}

Height, ${ }^{7} 7^{3}$ inches ; length, 30 inches

Etched by A. Brunet-Debaines, from the original picture by Vicat Cole. Artist's proof.

No. 345

\section{Thomas Carlyle}

Height, 17 inches; width, $13 \frac{1}{2}$ inches

Etched by Paul Rajon, after the original portrait by George Frederick Watts, R. A. One of the earliest proofs, with fourteen remark-heads sketched in dry-point, and bitten in, upon the margin, according to the custom of the artist of testing his tools and the strength of his acid while his work was in progress ; some of the remarkheads being apparently drawings from life, and others imaginative sketches or made from memory.

No. 346

\section{The Cornfield}

Height, I9: inches; width, I7 inches

Etched by A. Brunet-Debaines, after the original painting by John Constable. Artist's proof impression. A reproduction of the masterpiece of the great English landscape painter, in the British National Gallery. 
No. 347

\section{The Syndics}

Height, 23 inches ; length, 34 inches

Etched by Charles Koepping, after the painting by Rembrandt at Ansterdam. One of the unique edition of one hundred and twenty-five artist's proofs; the plate destroyed. Koepping was born in Dresden, Saxony, in I848, and studied chemistry, which he abandoned for art. After working as student and painter in Munich, he went to Paris in 1876 , and meeting there with the great etcher Waltner, had his attention seriously turned to etching. His plate of "The Syndics," at the Salon of I887, immediately placed him on a footing with the greatest reproductive etchers of modern times. Since ISgo he has been at the head of the school of engraving and etching attached to the Royal Academy of Fine Arts, Berlin. He is a Chevalier of the Legion of Honor, and a member of various academies.

No. 348

\section{The Syndics}

Same as No. 347 , above described.

No. 349

\section{Parting Day}

Height, $18 \frac{1}{2}$ inches; length, 30 inches

Etched by A. Brunet-Debaines, from the painting by B. W. Leader, R.A. Artist's proof. 
No. 350

\section{Evening on the Oise}

Height, 16 inches; length, 26 inches

Remark proof etching by Charles A. Walker, after the original picture by Charles François Daubigny. Charles A. Walker, born in London, N. H., in I848, began as an engraver on wood, became a steel engraver, invented the monotype process from original motives, and next turned his attention to etching, producing both original and reproductive plates. "With the sole exception of "Solitude,' etched by Chauvel, no Daubigny reproduction has been so successful as the 'On the Oise.'" Parchment.

No. $35 \mathrm{I}$

\section{Evening on the Oise}

Another impression of the above described, No. 350.

No. 352

\section{La Rixe}

Height, I7 inches ; length, 22 inches

Etched by Felix Bracquemond, from the original painting by Meissonier, presented by the Emperor Napoleon III. to Queen Victoria and the Prince Consort, and now in the private collection of the Queen of England. Remark proof. The remark is a portrait of Meissonier on horseback, etched by himself, on the margin of the plate. Signed by artist and etcher. Felix Bracquemond was born in Paris in I833. He studied painting under Joseph Guichard and Ingres, and received medals at the Salon for his pictures in oil, and later as an etcher. $\mathrm{He}$ is an Officer of the Legion of Honor, etc., and is the greatest of living French etchers. This plate, for which Queen Victoria loaned the original picture to the etcher for reproduction, is now entirely out of print in all the early states. It was etched in 1885 . 
No. 353

\title{
La Rixe
}

Same as No. 352 above described.

\section{ENGRAVINGS}

No. 354

\section{The Madonna Della Scala}

\author{
Height, $\mathrm{I} 9 \frac{1}{2}$ inches ; width, $\mathrm{I}_{4}$ inches
}

Line engraving by Paolo Toschi, after the original picture by Correggio. Remark proof before letters. Toschi was born at Parma in 1788 , went to Paris in 1809 and there studied under Bervic. $\mathrm{He}$ was an engraver of masterly experience and a solid style. In 18 I9 he returned to Parma and established there a school of engraving, being also made Director of the Academy of Fine Arts. Among his works was the series of engravings from the frescos of Correggio, at Parma, executed by his pupils under his direction. This plate is entirely his own work. He died in 1854 .

\section{No. 355}

\section{The Virgin and Angels}

\section{Height, 18 inches ; width, $\mathrm{I} 2 \frac{1}{2}$ inches}

Line engraving by Alphonse François, after the original picture by W. A. Bouguereau. Artist's proof. François was born in Paris in I8II, and was a pupil of the Ecole des Beaux Arts and of Henrique Dupont. He first exhibited in the Salon of 1842 , was made an Officer of the Legion of Honor in 1867 , and a Member of the Institute in 1873 . Among his plates are some which are accounted among the best productions of modern engraving. 
No. 356

Christ, St. John, and Angels

Height, 16 inches : length, $17 \frac{1}{8}$ inches

Line engraving by Givotia Garavaglia, after the painting by Carlo Maratta. Garavaglia was a native of Milan, and a pupil and follower of Giuseppe Longhi, who founded the Milanese school of engraving in the last century.

No. 357

\section{The Immaculate Conception}

Line engraving by Achille Lefevre, after the painting by Murillo. Proof. Lefevre was born in Paris in 1798 . He was at first an engraver of portraits, but later essayed more ambitious work. This plate is a reproduction of the picture now in the Louvre; which was brought to France by Marshal Ney after the Peninsular Campaign in Spain under Napoleon I. It was engraved about 1833 . The picture is known in the French catalogues as "L'Annonciation." Lefevre was made a Member of the Legion of Honor in I85I. Died in I864. 
No. 358

\section{The Transfiguration}

Height, $28 \frac{1}{2}$ inches ; length, $19 \frac{1}{2}$ inches

Line engraving by Raphael Morghen, after the picture by Raphael. Open letter proof. Raphael Sanzio Morghen was born near Naples in I758. He was the pupil of his father and uncle, and of Volpato in Rome. He devoted himself to engraving historical portraits and the masterpieces of the old Italian masters, and won a reputation which extended throughout the world. He died at Florence in 1833 , and his death was lamented in Italy as a national calamity. A public monument to his memory was erected in the Church of Santa Croce in Florence. He was, at his death, court engraver to the Grand Duke of Tuscany. The Transfiguration was engraved by him in I8I I, and constituted his work of the year. It was the engraving with which he was introduced, at the invitation of Napoleon I., to Paris, in the Salon of I8I2.

No. 359

\section{The Last Supper}

Height, $x_{7}$ inches; length, $35^{\frac{1}{4}}$ inches

Line engraving by Raphael Morghen, after the fresco by Leonardo da Vinci. Proof, with dedicatory line on plate, before letters. This is the engraver's masterpiece, as conceded by all authorities on the art of engraving. It is accepted as the best representation of the picture in existence. The original work was a fresco, and was badly used during the wars. It was then quite as badly restored. Morghen made a careful study of it, secured all that he could secure of the painter's original studies for it, and, adhering closely to his originals, has given us the best, and, indeed, the only true version of Da Vinci's "Last Supper" which we possess to-day. Morghen spent three years engraving this plate, and it ranks as his masterpiece. 
No. 360

\section{Aurora}

Height, $7_{\frac{1}{4}}^{\frac{1}{4}}$ inches ; length, $35^{\frac{3}{4}}$ inches

Line engraving by Raphael Morghen, from the painting by Guido Reni. Proof before letters. “Morghen's reputation was soon afterwards established upon the appearance of his well-known plate of the Aurora, from Guido's fresco in the Rospigliori Palace."-WiLLIs O. CHAPIN : The Masters and Masterpieces of Engraving.

No. $36 \mathbf{I}$

\section{Magdalaen}

Height, II inches; length, $I_{5}$ inches

Line engraving by Giuseppe Longhi, after the painting by Correggio. Longhi was born at Monza, in Italy, in I766. He was intended by his family for a monk, but became an engraver. He was a pupil at the art of Vincenzio Vangelisti of Florence, who had been a pupil of Wille. Going later to Rome, he met Raphael Morghen, and was influenced as well as instructed by him. He won recognition, and established the school of engraving at Milan, in connection with which he was recognized as a great teacher. The Magdalaen, which he engraved from the picture in the Dresden Gallery, is described by Willis O. Chapin as an "exquisite engraving." Longhi died in Milan, in $183 \mathrm{I}$. 
No. 362

\section{The Communion of St. Jerome}

Height, $28 \frac{1}{2}$ inches; length, $17 \frac{1}{\frac{1}{2}}$ inches

Line engraving by Pierre Alexandre Tardieu, after the painting by Domenichino. Tardieu was born in Paris in I756. With Bervic, to whom he succeeded as Member of the Institute in 1822 , he provided the connecting link in the transition period between the great engravers of the past and the present centuries. His chief employment was in portraits, but such subject engravings as he made were of the highest character. For this plate, which he engraved in $182 \mathrm{I}$, and exhibited in $\mathrm{I} \$ 22$, he received the Legion of Honor and was admitted into the Institute. Beraldi, "Graveurs," etc., Part I2, says of it : "One of the most remarkable pieces of engraving of this century." Tardieu died in $18+4$.

No. 363

\section{Diana}

Height, $18 \frac{1}{2}$ inches; length, $17 \frac{1}{2}$ inches

Line engraving by C. Raimondi and Paolo Toschi, after the picture by Correggio. Proof before letters, with remark and inscription. Raimondi was a pupil of Toschi, working very closely to his master's style, and upon the death of Toschi took his place as head of the engraving school at Palma. 
No. 364

\section{Paternal Advice}

Height, 18 inches; length, 14 inches

Line engraving on copper, by John George Wille, after the painting by Gerard Terburg. Wille, although claimed by the French school of the last century, was born at Königsberg, Germany, in I7I7. He established himself in Paris, where he married, and where his son P. A. Wille, many of whose pictures the father engraved, was born. The "Satin Gown," as this plate is called from the dress of the young matron whose father and mother have come to visit and advise her, is one of his acknowledged masterpieces. Wille died, at the age of $9 \mathrm{I}$ years, in Paris.

No. 365

\section{The Madonna of San Sisto}

Height, 26 inches ; length, 20 inches

Line engraving by Friederich Müller, after the original picture by Raphael in the Dresden Gallery. Müller was the son of Johann Gotthard Müller, court engraver to the King of Wurtemberg, was born at Stuttgart in 1782 , and a pupil of his father, and in Paris of Wille, Bervic, Tardieu, and Desnoyers. This plate, which is his masterpiece, was completed by him in I8I5. He rested great hopes upon it, and undertaking to publish it himself, it proved a business failure, whereupon he killed himself, with one of his own engraving tools, on May 3, I816. This plate has since been recognized as one of the best line engravings of his time, and has made him famous. 
No. 366

\section{La Joconde}

Height, 15 inches ; width, $x$ inches

Line engraving on steel, by Luigi Calamatta, from the original picture by Leonardo da Vinci. Presentation proof from the engraver to $M$. Chatin. Calamatta was born in I8OI at Civita Vecchia, studied engraving in Rome, settled and worked in Paris, and won all the possible medals. He returned to Italy in $186 \mathrm{I}$, became a volunteer under Garibaldi in $\mathbf{1 8 6 6}$, and died at Milan in r869. He is now buried in his native town, under a monument erected to him by public subscription.

No. 367

\section{The Nest}

Height, $x^{2} \frac{1}{2}$ inches ; width, $x_{4}$ inches

Mezzotint by G. W. H. Every, after the picture by Sir J. E. Millais, R.A. Artist's proof. The reproducer belongs to the revival school of mezzotinting, brought into existence in England by Hubert Herkomer and the Slocombes.

No. 368

\section{The Love Bird}

Height, 18 inches; width, $\mathrm{x}_{3}$ inches

Mezzotint by Fred. Atkinson, from the picture by Sir J. E. Millais. Artist's proof. Atkinson is an English mezzotinter of excellent reputation in the school which has grown out of the modern revival of the art. 
No. 369

\section{The Descent from the Cross}

Height, $28 \frac{1}{2}$ inches ; width, $x_{9}$ inches

Line engraving by L. Toschi, after the painting by D. R. Volterra. Proof, with the round remark on the arm of the cross.

No. 370

\section{Phyllis}

Height, $19 \frac{1}{\frac{1}{3}}$ inches ; width, $14 \frac{1}{\frac{1}{4}}$ inches

Mezzotint by H. Scott Bridgewater, after the painting by Luke Fildes. Artist's proof. Bridgewater was born at Dudley, Eng., in 1864, was a student at the Dudley School of Art, and at the Herkomer School of Engraving at Bushey. He devoted himself entirely to mezzotint, exhibited first at the Royal Academy in 1888 , and acquired his initial reputation through this plate.

No. $37 \mathbf{I}$

\section{Apollo and the Muses}

Height, 7 inches; length, 30 inches

Line engraving by J. B. R. U. Massard, after the picture. by Julio Romano. Artist proof. Jean Baptiste Raphael Urbain Massard was a son of the great engraver Jean Massard, and the most gifted of his family. He was born in Paris, and was schooled in his art by his father. He was decorated in 1824 , and was at the height of his renown when he suddenly ceased to produce. He died in 1849 . This plate was engraved by him in I8I2. 
No. 372

\section{La Bella}

Height, $I_{5} \frac{1}{2}$ inches; width, $I I_{\frac{1}{2}}^{\frac{1}{2}}$ inches

Line engraving by Edward Mandel, after the picture by Titian, supposed to be a portrait of the Duchess of Urbina. India proof, with remark on the upper edge of the plate. Mandel was born in Berlin in 1810 , and was a protégé of King Frederick William III. He studied at the Academy of Fine Arts from his sixteenth year, remaining four years under Professor Buchhorn, and in I830 made such a remarkable hit with an engraving after Hildebrand, that he was appointed by the Academy to engrave the "Loreley," painted by Begas. He re. ceived his first medal in Paris in 1840 , was appointed professor of painting at Berlin in 1842 , died in $\mathbf{I} 882$.

No. 373

\section{Two Children}

Size, $\mathbf{r}_{3}$ inches by $\mathrm{I}_{3}$ inches ; circular

Line engraving by Edward Mandel, after the painting by Edward Magnus. Proof before letters, I843. This was one of the group of plates which won for Mandel his first class medal at the Paris Universal Exposition of I855.

No. 374

\section{The Madonna della Sedia}

Size, 12 inches by 12 inches ; circular

Line engraving by Edward Mandel, from the painting by Raphael. India proof. Signed, I 865. 
No. 375

\section{The Card-Players}

Height, 20 inches; width, $16 \frac{1}{2}$ inches

Line engraving on steel by Lumb Stocks, after the painting by Thomas Webster, R.A. Proof before letters, I85I. Lumb Stocks was born at Lightcliffe, Yorkshire, in I8I2, and by common consent ranks as one of the best English line engravers. $\mathrm{He}$ is a member of the Royal Academy, and now lives in retirement. This plate was engraved by him for the Fine Arts Association of Scotland.

No. 376

\section{An Old Pensioner}

Height, 24 inches ; width, 15 inches

Engraved on steel by W. H. Simmons, after the painting by Rosa Bonheur. Artist's proof. The head of an old donkey, long used as a model by the artist, and now living out its old age in comfort on her farm.

No. 377

\section{A Daring Highway Robbery}

Height, ${ }_{5} \frac{1}{2}$ inches; width, $I_{\frac{1}{2}}^{\frac{1}{2}}$ inches

Mezzotint and line by Charles A. Tompkins, after the picture by Wm. Weekes. Artist's proof. Tompkins is one of the new school of English mezzotinters, who has recently acquired prominence. 
No. 378

\section{St. John}

Height, I 3 inches; width, Ir inches

Line engraving by Frederick Müller, after the original picture by Domenechino. Proof before letters.

No. 379

\section{Portrait}

Height, $4 \frac{1}{2}$ inches ; width, $3 \frac{1}{\frac{1}{2}}$ inches

Line engraving by Paul Mercuri, second state, unlettered proof, 1843 . Mercuri was born in Rome in 1804, and was a painter as well as an engraver. He worked from 1830 to 1847 in Paris, but returned to Rome in 1847 and became Professor of Engraving at the Academy of Fine Arts. He was a member of the Academy of St. Luke, and died at Bucharest in 1884 .

No. 380

\section{Spare the Weeds}

Height, I 8 inches ; length, 24 inches

Steel engraving by Arthur Turrell, after the painting by G. B. O'Neill. An old gardener weeding his garden, while a little girl gathers the wild flowers which he is uprooting. 
No. $38 \mathbf{I}$

\section{Christmas Morning}

Height, 24 inches; width, Ig inches

Steel engraving by G. C. Barnes. A little girl, who has stolen out of bed on Christmas morning, is descending the stairs to show to the family the presents Santa Claus has left her. Artist proof.

No. 382

\section{Conquered but not Subdued}

$*$

Height, 22 inches; length, 30 inches

Steel engraving by J. J. Chant, after the painting by Thomas Faed. A Scottish cottage interior, with a stubborn urchin who has been rebuked for an offence sullenly submitting to the disgrace which he cannot escape. Open letter proof.

\section{WATER COLORS}

No. 383

D. RIDGWAY KNIGHT,

UNITED STATES

\section{The Water Girl}

Height, ${ }_{5}$ inches; width, II inches

A peasant girl of the North of France is carrying the empty water-jugs of the farm to the brook for replenishment, crossing the fields by a footpath and gazing across them as if she might discern a rustic admirer in the distance. Signed at the left, 1885 . 
No. 384

JOSEF ISRAELS, HOLLAND

\section{No Place Like Home}

Height, ro inches ; length, ${ }_{4}^{\frac{1}{3}}$ inches

A Dutch farm wife, who has returned from market, sits at her comfortable kitchen fireside in company with her cat, and warms herself after her journey. Signed at the right.

No. 385

ALBERT NEUHUYS,

HOLLAND

\section{Luncheon Time}

Height, $2 \mathrm{I}_{2}^{\frac{1}{2}}$ inches ; length, 26 inches

Three Dutch peasant children are seated under a kitchen window for their noonday refection, which the elder girl serves out to them. Signed at the right.

No. 386

R. DE CUVILLON,

FRANCE

\section{Her Answer}

Height, 18 inches ; width, I2 $\frac{1}{2}$ inches

A young and pretty lady in costume of the seventeenth century is seated at a table writing a note of recognition to her sweethearl, who has sent her a bouquet of roses. Signed at the right. 
No. 387

HENRI HARPIGNIES,

FRANCE

\section{On the Seine}

Height, $12 \frac{2}{8}$ inches; length, 18 inches

A scene on the Seine above Paris, with a wide reach of country seen from an elevated foreground, and a suggestion of the city in the remote distance. Signed at the left, 1883 .

No. 388

WINSLOW HOMER,

UNITED STATES

Ready for the Hunt

Height, $\mathrm{r}_{4}$ inches ; length, 20 inches

A pack of hounds in a barge moored in an Adirondack lake await the coming of the hunters to unleash them and start them on the chase. Signed at the left, I889.

No. 389

V. CHEVILLARD,

FRANCE

\section{Kindly Assisting}

Height, Ir inches ; width, $8 \frac{1}{4}$ inches

A country curé, who has called upon an old lady member of his flock, is holding a skein of yarn for her to make into a ball, and enlivening the operation with the gossip of the day. Signed at the left. 
No. 390

ADOLPHE ARTZ,

HoLLAND

\section{Rustic Flirtation}

Height, 22 inches; width, $14 \frac{1}{2}$ inches

A Dutch shepherdess leans against a fence, knitting a stocking, and listening to the pleadings of a young farm laborer, who has ceased his labor to indulge in the pleasure of a flirtation. Signed at the right.

No. 391

JOSEF ISRAELS,

HOLLAND

\section{Preparing Her Wedding Garment}

Height, $x_{3}$ inches; width, 8 inches

A Dutch country girl, sewing industriously upon the linen which is to form part of her wedding outfit. Signed at the left.

No. 392

JOSÉ VILLEGAS,

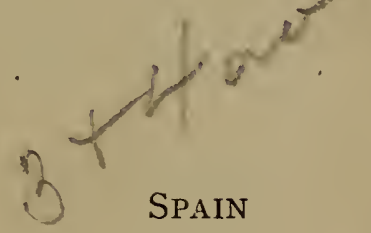

\section{At the Armorer's}

Height, 18 inches ; width, $12 \frac{1}{8}$ inches

A Moorish soldier, examining a long-barrelled flintlock gun, whose desirable character is explained by the armorer, who is seated on the divan beside him. Signed at the right. 
No. 393

HUBERT HERKOMER,

ENGLAND

\section{Learning to be Useful}

Height, $6 \frac{8}{4}$ inches; length, $9 \frac{5}{8}$ inches .

A little Bavarian country girl is receiving a knitting lesson from her mother, while her younger brothers and sisters look on with interested curiosity. Signed at the right, I 885 .

No. 394

ERSKINE NICOL,

ENGLAND

\section{Head of Her Class}

Height, 68्a inches; length, 9 inches

A little Scotch school-girl, returning from school, where she has won a place at the head of her class, is being congratulated by her grandfather and grandmother, who show their pride and pleasure at the distinction she has won ; while her brother, who has probably gone to the foot of his class, looks on from the doorway, in no haste to encounter the reproaches which he has deserved. Signed at the left, $188_{3}$.

No. 395

H. CAFFIERI,

ENGLAND

\section{Shutting the Lock Gate}

Height, 27 inches ; width, 20 inches

Two buxom country girls, who lean against the gate beam of a canal lock, to close the water-gates after some boat has passed out of the lock. Signed at the left. 
No. 396

WINSLOW HOMER, United STATES

\section{The Feeding Place}

Height, ${ }_{4}$ inches; length, 20 inches

At the margin of an Adirondack lake a doe, which has come down into the water to feed on the lily-pads, looks around to make certain of security before commencing her meal. Signed at the right, I889.

No. 397

MARGARETA ROOSENBOOM, HOLLAND

\section{Flowers}

Height, $\mathrm{I}_{4}$ inches ; length, zo inches

A study of cut flowers. Signed at the right.

No. 398

JOSEF ISRAELS,

\section{When Age Creeps On}

Height, ${ }_{3} 3$ inches; width, ro inches

An old Dutch peasant woman, seated on a low stool, and bending over a smouldering turf fire in a kitchen chimney. A modified version of the artist's picture in oil entitled, "When One Grows Old." Signed at the left. 
No. 399

MARGARETA ROOSENBOOM, HOLLAND

\section{Flowers}

Height, $2 \mathrm{O}_{2}^{\frac{1}{2}}$ inches ; width, $\mathrm{I}_{4} \frac{1}{2}$ inches

A study of flowers in a jar. Signed at the left.

No. 400

WINSLOW HOMER,

United STATES

\section{The Guide}

Height, $\mathrm{I}_{4}$ inches ; length, 20 inches

An old guide and hunter, in his skiff on the forestenclosed waters of an Adirondack lake, is exploring the shore for the trail of, deer or for signs of game coming to feed and drink. Signed at the left.

No. 4 I I

H. DE MARTIN,

FRANCE

\section{Turkish Lady}

Height, 6 inches; width, 3 inches

The half-length standing figure of an Oriental woman in the gayly colored negligé costume of the household. Signed at the left, I882. 


\section{No. 402}

MARGARETA ROOSENBOOM,

\section{Flowers}

Height, $x_{3}$ inches ; length, 21 inches

Cut flowers picturesquely shown on a stone wall. Signed at the right.

No. 403

\section{FERDINAND HEILBUTH, FRANCE}

\section{Two Friends}

\section{Height, ${ }_{7}$ inches ; length, 23 inches}

A lady and her pet dog upon the grassy summit of a cliff overlooking the sea, on a summer morning. Signed at the right, 1880.

No. 404

MARTIN RICO,

SPAIN

\section{River View in Italy}

Height, I5 $_{5}$ inches ; length, 2r inches

An Italian landscape, under a very bright, sunny, summer effect. Signed at the centre. 
No. 405

DWIGHT IV. TRYON,

UNITED STATES

\section{Moonrise}

Height, ro $\frac{1}{2}$ inches; length, $13 \frac{1}{2}$ inches

An autumn moonrise, with farm buildings showing in the middle ground against the sky. Signed at the left.

No. 406

MRS. C. W. CONANT,

United States

\section{In the Garden}

Height, $\mathrm{I}_{4}$ inches ; length, 18 inches

A lady and little girl in a garden, arranging in bouquets the flowers they have gathered. Signed at the right.

No. 407

WILLIAM T. RICHARDS, UNITED STATES

\section{Low Tide}

Height, I2 inches; length, 23 inches

The seashore, at evening, under a showery sky, with the gentle breakers which characterize an ebb-tide. Signed at the left, 1883 . 
No. 408

HENRI HARPIGNIES,

\section{Landscape}

Height, 20 inches ; width, $14 \frac{1}{2}$ inches

From the margin of a wood on a hilltop, the view extends over a wide prospect of country, dotted with villas, in full summer sunshine. A scene in the South of France, on the Mediterranean coast. Signed at the left, $\mathbf{1} 882$.

No. 409

EDWARD MORAN, United States

\section{Waiting for the Tide}

Height, 35 inches ; width, 22 inches

A Normandy fisher-woman, on the seashore, prepared to go shrimping, and waiting until the tide shall turn so as to serve her purposes. Signed at the left, $188_{3}$.

No. 410

FREDERICK W. FREER, UNITED STATES

\section{Reminiscence}

Height, 25 inches ; width, 20 inches

A young lady, seated, contemplates some flowers in a water globe, which seem to remind her of a pledge of passion past and forgotten by all but her. Signed at the left, on top, 1886. 
I48 ESTATE OF THE LATE GEORGE I. SENEY

No. 4 I I

HENRI HARPIGNIES,

FRANCE

\section{Moonrise}

A brook at the edge of a wood, with the moon rising in a clear sky. The time is autumn. Signed at the left, I882.

AMERICAN ART ASSOCIATION,

MANAGER.

THOMAS E. KIRBY, AUCTIONEER. 



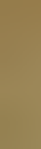

: 


SMITHSONIAN INSTITUTION LIBRARIES

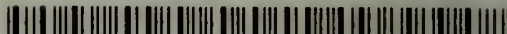

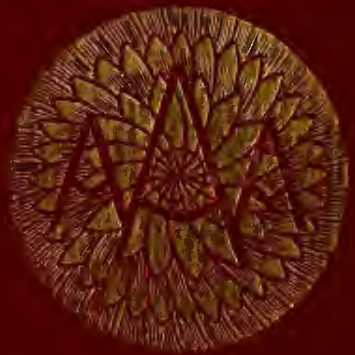

